\title{
Article
}

https://doi.org/10.11646/phytotaxa.365.2.1

\section{Austronea (Asparagaceae, Scilloideae), a new genus from southern Africa, including the description of seven new species}

\author{
MARIO MARTÍNEZ-AZORÍN ${ }^{1 *}$, MANUEL B. CRESPO ${ }^{1}$, MARÍA ÁNGELES ALONSO-VARGAS ${ }^{1}$, ANTHONY P. \\ DOLD $^{2}$, MICHAEL PINTER ${ }^{3} \&$ WOLFGANG WETSCHNIG ${ }^{3}$ \\ ${ }^{I}$ dCARN (Depto. Ciencias Ambientales y Recursos Naturales) y CIBIO (Instituto Universitario de la Biodiversidad), Universidad de \\ Alicante, P.O.Box 99,E-03080 Alicante,Spain; e-mail:mmartinez@ua.es \\ ${ }^{2}$ Selmar Schonland Herbarium, Department of Botany, Rhodes University, Grahamstown 6140, South Africa. \\ ${ }^{3}$ Institute of Biology, Division Plant Sciences, NAWI Graz, Karl-Franzens University Graz, Holteigasse 6, A-8010 Graz, Austria. \\ "author for correspondence
}

\begin{abstract}
As part of a taxonomic revision of Urgineeae, combining morphological and genetic data from numerous samples from a large range of its distribution, here we describe Austronea, a new genus from South Africa and southern Namibia. This genus is related to Fusifilum based on general inflorescence and flower morphology, but it differs from it by the leaves usually leathery and sometimes thickened; the capitate to subcorymbose raceme commonly nodding at early developing stages; the reddish to green-yellowish tepals, rarely white (see flower buds), which are usually connate at the base to form a distinct cup and patent free lobes, rarely tepals nearly free from the base; the filaments linear to lanceolate, smooth or rarely papillate below; and the ovary green to yellow-orange. These differences are also supported by our genetic studies (not shown) in which Fusifilum and Austronea form two well supported sister clades. Seven new species of Austronea are described from South Africa and Namibia and 11 new combinations in the genus are presented. An identification key is provided for all 18 accepted species in the new genus.
\end{abstract}

Key words: Hyacinthaceae, distribution, ecology, nomenclature, taxonomy, Urgineoideae

\section{Introduction}

Hyacinthaceae include ca. 1000 species of bulbous plants distributed in Africa, Europe and Asia, with a single genus, Oziroë Rafinesque (1837: 53), in South America (Speta 1998a, 1998b, APG 2003). Four monophyletic subfamilies are accepted in Hyacinthaceae: Hyacinthoideae, Ornithogaloideae, Oziroëoideae, and Urgineoideae (Speta 1998b, Pfosser \& Speta 1999, Manning et al. 2004, Martínez-Azorín et al. 2011). Alternatively, Hyacinthaceae is treated as part of Asparagaceae, subfamily Scilloideae, and consequently subfamilies are reduced to tribes: Hyacintheae, Ornithogaleae, Oziroëeae and Urgineeae (APG 2009, 2016, Chase et al. 2009).

Generic circumscriptions of subfamily Urgineoideae has become controversial especially in recent decades (Speta 1998a, Manning et al. 2004, Martínez-Azorín et al. 2013a, 2013b, 2016, 2017, Crouch \& Martínez-Azorín 2015). Previous phylogenetic studies in Urgineoideae strongly support multigeneric arrangement in Urgineoideae (Pfosser \& Speta 2001, 2004, Pfossser et al. 2012), involving recircumscription of some genera. As shown by Martínez-Azorín et al. (2011) in subfamily Ornithogaloideae, when sufficient plastid and nuclear DNA regions are included in the phylogenetic analyses, consistent morphological elements are fully congruent with clades, and these can be accepted at the generic rank. A similar study in Urgineoideae is ongoing, that supports the recognition of a multigeneric treatment in the subfamily (M. Martínez-Azorín and collaborators, in preparation), where some new genera have been already described based on solid genetic and morphological evidence: Sagittanthera Martínez-Azorín et al. (2013b: 46), Mucinaea Pinter et al. (2013: 296), Aulostemon Martínez-Azorín et al. (2017: 288) and Iosanthus Martínez-Azorín et al. (2018: in press).

Among the genera in Urgineoideae, Fusifilum Rafinesque (1837:27) was described as "Fusifilum R. (spindle fil) Diff. 67 [Anthericum] Stam. glabris fusiformis ad medio dilatatis. $3 \mathrm{sp}$. Phalangium physodes, pusillum Jacq. 
W. coarctatum RP. Pers, \& c.”, to include some species described by N.J. Jacquin as Anthericum physodes Jacquin (1795: 18) and A. pusillum Jacquin (1795: 18) (Fig. 1). Later, Physodia Salisbury (1866: 37) was described to include "Species 1. Anthericum Physodes Jacq. Cfr. Pusillum ejusdem." and was characterized among other characters by the "Filamenta patentia, clavato-attenuata, inferne pubescentia". Physodia Salisbury (1866: 37) has been considered as a synonym of Fusifilum in recent works. At present, 17 species are accepted in Fusifilum (Müller-Doblies et al. 2001, Tang \& Weiglin 2001, Martínez-Azorín et al. 2015), that form a coherent group easily identified by a distinct morphology such as the stellate flowers with spreading, free tepals, white on the adaxial side with a greenish to purplish longitudinal band on the abaxial side; filaments fusiform and widened in the middle, distinctly papillate on the lower portion; ovary white or tinged with violet or purple, ovate-oblong and commonly truncate to the apex; inflorescence erect at all developing stages; and seeds commonly elliptical in outline, flat and widely winged on the margins (Figs. $1-2)$.

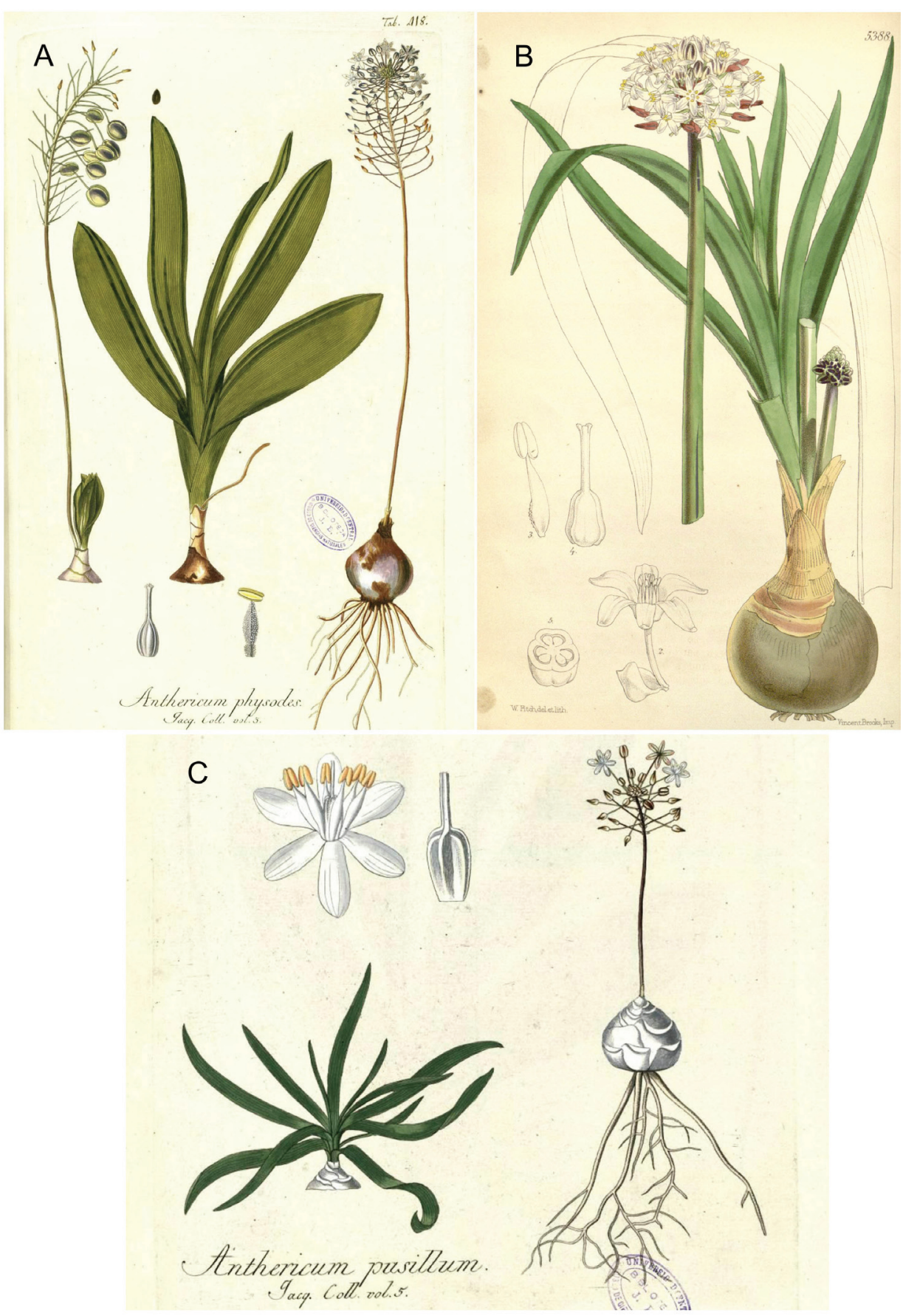

FIGURE 1. Plate showing general morphology of Fusifilum species with white flowers and ovary, and fusiform, papillate filaments. A. Fusifilum physodes (Jacq.) Raf. as Anthericum physodes in Jacquin (1795: 18); B. Fusifilum capitatum (Hooker 1863: t. 5388) Speta (1998: 69) as Ornithogalum capitatum in Hooker (1863: t. 5388); C. Fusifilum pusillus (Jacq.) Speta as Anthericum pusillus in Jacquin (1795: 18). 

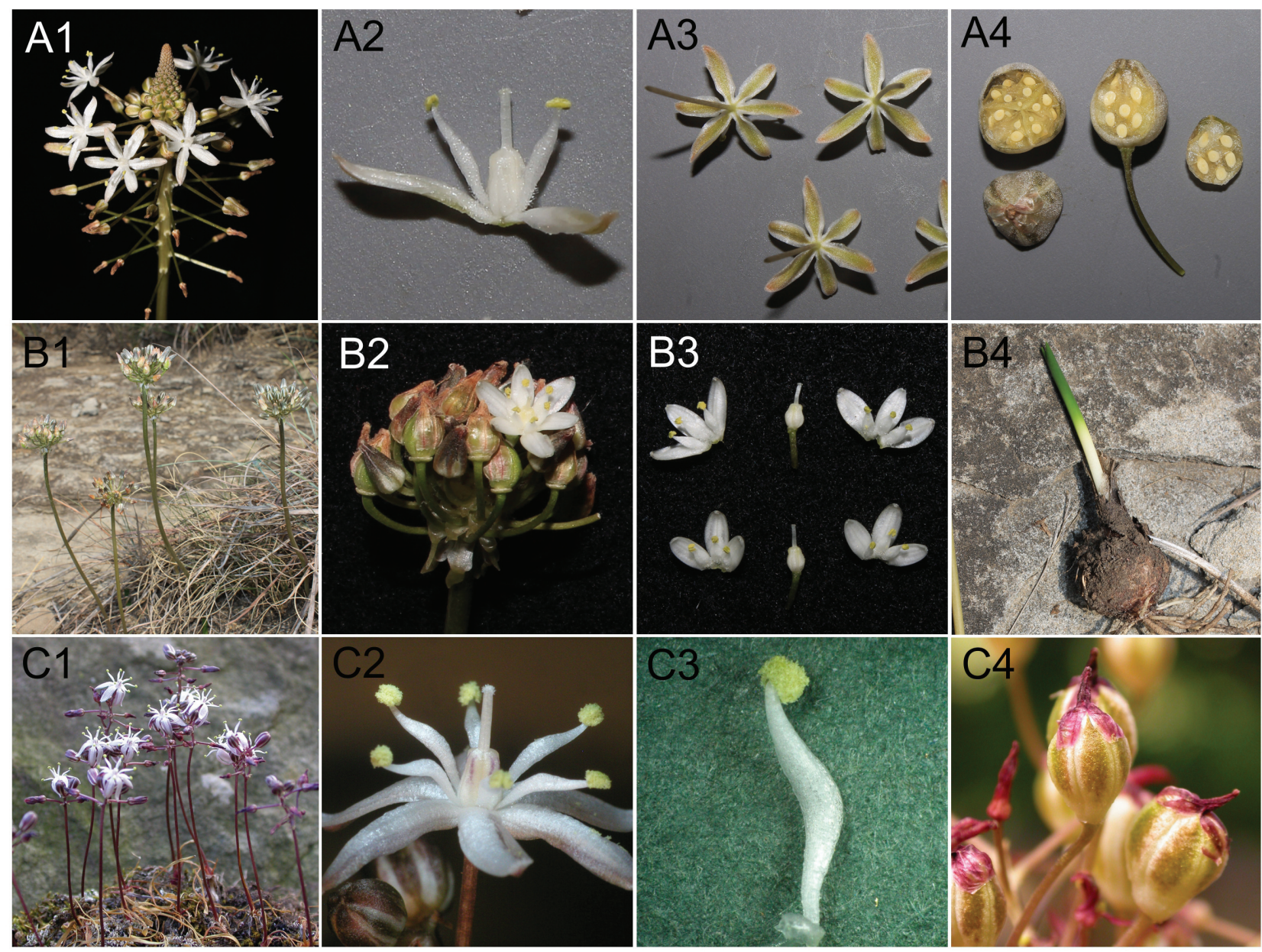

FIGURE 2. General morphology of living samples of Fusifilum showing white flowers and ovary, and fusiform, papillate filaments. A. F. physodes in cultivation corresponding to WW4159 (L.Mucina 021009/03); B. F. capitatum, from Van Reenen Pass, South Africa, corresponding to MMA1392; C. F. montanus from Groot Winterberg, Tarkastad, South Africa, corresponding to Dold \& Cocks 4633 (GRA).

Our studies in Urgineoideae demonstrate that some species traditionally included in Urginea Steinheil (1834: 321) or Drimia Jacquin (1797: 38) sensu lato resemble those of Fusifilum, but differ by distinct morphological characters, such as the leaves usually leathery and thickened; the subcorymbose or congested raceme commonly nodding at early developing stages, the reddish to green-yellowish tepals (see flower buds), which are usually connate at the base to form a distinct cup and patent free lobes, the filaments linear to lanceolate (not distinctly fusiform), smooth or rarely papillate below, the ovary green to yellow-orange, and the seeds commonly trigonous in outline, tetrahedrally folded and narrowly winged along the angles (Figs. 3-4), characterizing the new genus Austronea. Among those species we count Drimia acarophylla Brink \& Dold (2003: 396) (Fig. 3A), D. barkerae Oberm. ex Manning \& Goldblatt (2003: 109) (Fig. 3B), D. chalumnensis Dold \& Brink (2004: 631) (Fig. 3C), D. fimbrimarginata Snijman in Snijman \& Harrower (2009: 234), D. ligulata J.C.Manning \& Goldblatt in Martínez-Azorín \& Crespo (2014: 1330), D. marginata (Thunberg 1794: 63) Jessop (1977: 295) (Fig. 3D), D. pulchromarginata Manning \& Goldblatt (2007: 185) (Fig. 4A), D. trichophylla Martínez-Azorín et al. (2016: 944) (Fig. 4B), D. vermiformis J.C.Manning \& Goldblatt in MartínezAzorín \& Crespo (2014: 1330) (Fig. 4C), Urginea ecklonii Baker (1892: 6), Urginea pygmaea Duthie (1928: 10), and U. virens Schlechter (1897: 433).

Our ongoing phylogenetic studies in Urgineoideae, which include 16 samples of Fusifilum and 35 samples of Austronea, covering most of the accepted species in both groups and several new species in the latter genus, are based on plastidial and nuclear DNA regions of numerous samples, also covering most of the accepted species in this subfamily (M. Martínez-Azorín and collaborators, in preparation). The phylogenetic trees we obtained so far recover 
Fusifilum and Austronea as sister and well-supported monophyletic clades, demonstrating that these are evolutionary independent linages, facilitating the description of the latter as a new genus.

Therefore, based on the distinct differences with regards to Fusifilum and other Urgineoid groups commonly referred to a widely circumscribed Drimia, we here formally describe the new genus Austronea, including 18 species. Our field work in South Africa and Namibia in the last decade revealed that the knowledge of the genera involved was highly insuffient. This paper attempts to offer a remedy by presenting Austronea, including 11 new combinations for extant taxa, and presenting seven new species. Complete morphological descriptions and illustrations as well as data on ecology and distribution are included for all new species. An identification key is provided for all accepted Austronea species, to facilitate future studies in this taxonomically intricate group.
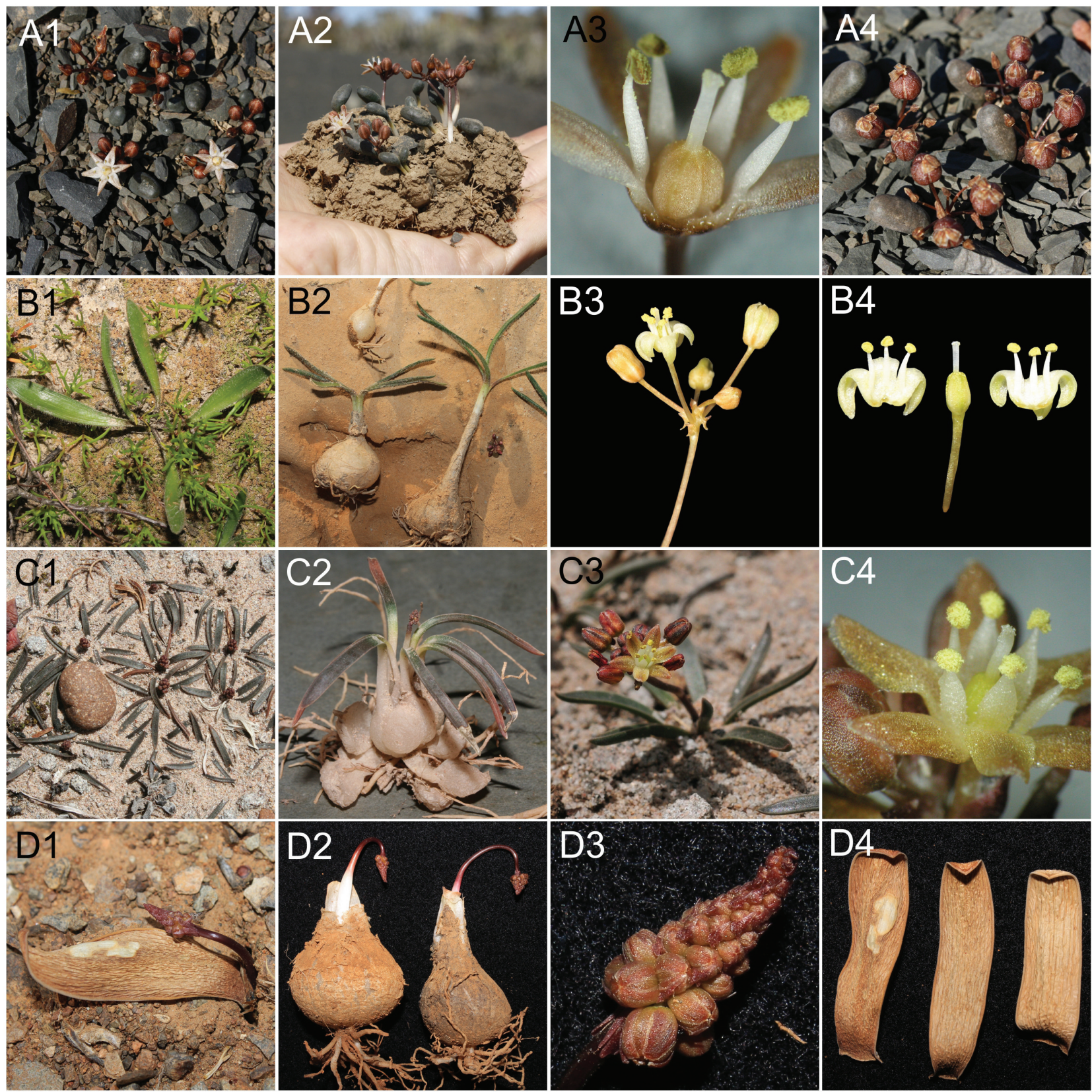

FIGURE 3. General morphology of species of Austronea. A. A. acarophylla (E.Brink \& A.P.Dold) Mart.-Azorín et al. from Great Fish river, Eastern Cape, South Africa corresponding to MMA1040; B. A. barkerae (Oberm. ex J.C.Manning \& Goldblatt) Mart.-Azorín et al. from SE of Redelinghuys, Western Cape, South Africa, corresponding to MMA1708; C. A. chalumnensis (E.Brink \& A.P.Dold) Mart.Azorín et al. from Chalumna river (type locality), Eastern Cape, South Africa, corresponding to MMA873; D. A. marginata (Thunb.) Mart.-Azorín et al. from W of Loeriesfontein, Northern Cape, South Africa, corresponding to MMA1293. 

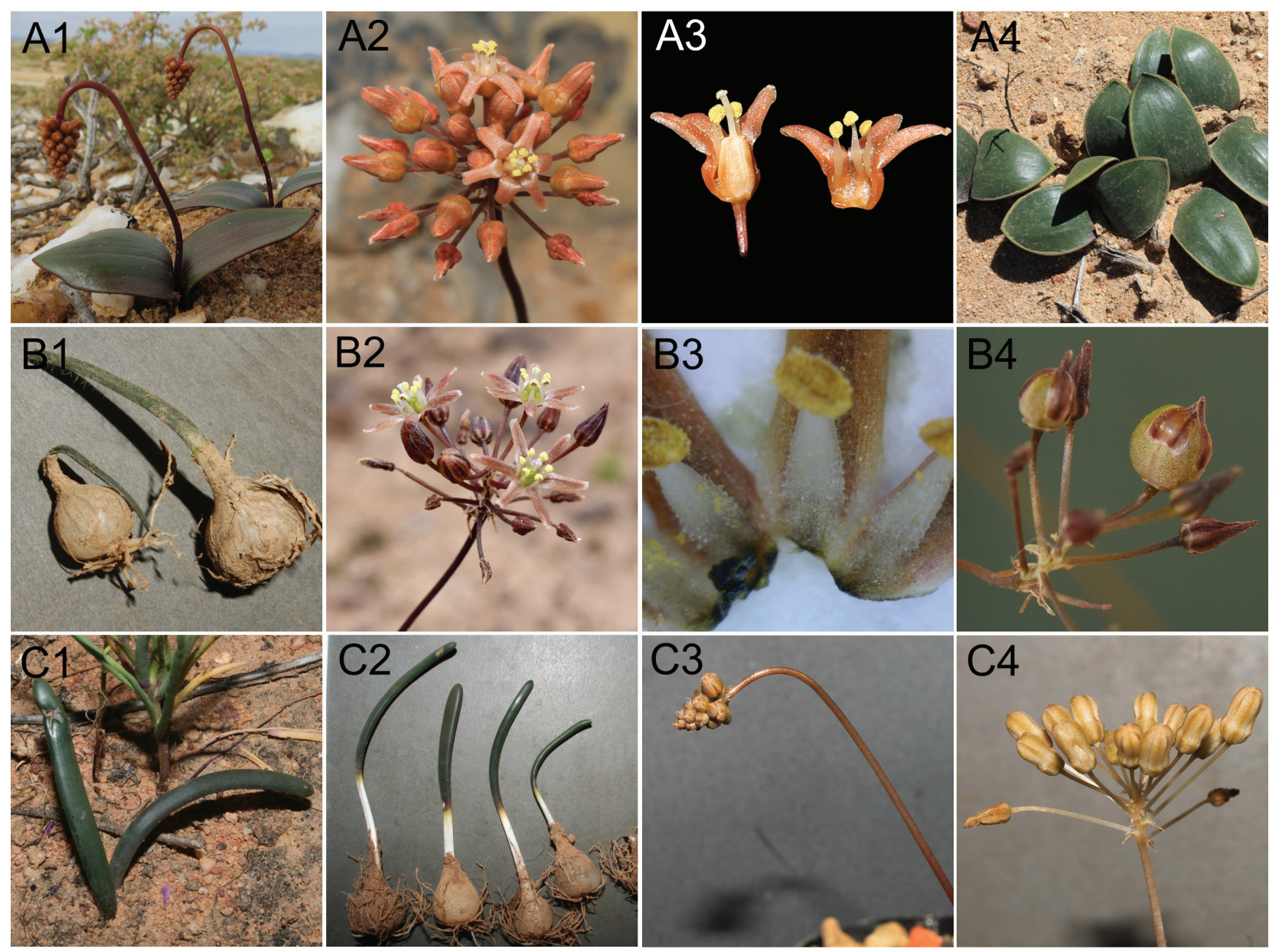

FIGURE 4. General morphology of species of Austronea. A. A. pulchromarginata (J.C.Manning \& Goldblatt) Mart.-Azorín et al. from Soebatsfontein (A1) (photo D. Human), Namakwa (A2-3) corresponding to MMA1242 and N of Kamieskroon (A4) corresponding to MMA1680, Northern Cape, South Africa; B. A. trichophylla (Mart.-Azorín et al.) Mart.-Azorín et al. from Table Fam (type locality), Grahamstown, Eastern Cape, South Africa corresponding to MMA613; C. A. vermiformis (J.C.Manning \& Goldblatt) Mart.-Azorín et al. from Clanwilliam (type locality), Western Cape, South Africa, corresponding to MMA796.

\section{Materials and methods}

Detailed morphological studies were undertaken on wild plants and cultivated specimens following the terminology used for species of Hyacinthaceae in Martínez-Azorín et al. (2007, 2009). Measurements of tepals, stamens and ovary were taken on fresh material. Herbarium specimens from the herbaria ABH, B, BLFU, BOL, GZU, GRA, K, M, MO, NBG, NU, NY, P, PRE, S, TCD, UPS, W, WU, Z, ZSS, and ZT (herbarium acronyms according to Thiers 2018) were studied. Orthography of geographical names and grid-number system follow Leistner \& Morris (1976). Nomenclatural issues accord with the Shenzhen Code (Turland et al. 2018).

\section{Description of the new genus}

Austronea Mart.-Azorín, M.B.Crespo, M.Pinter \& Wetschnig gen. nov.

Genus notabilis ad Fusifilum similis, sed singulari characterum combinatione ab eo et ceteris generibus Urgineoideae diversus et facile distinguendus, nempe foliis generaliter coriaceis, incrassatis vel incrassato-coriaceis; inflorescentia saepissime subcorymbosa vel capitata, juniore plerumque nutante; perigoniis in alabastro rubescentibus vel viridi-lutescentibus, tepalis saepissime a basi bene cupulato-connatis lobis patentibus (rarissime lobis usque ad basem liberis); filamentis staminibus linearibus vel lanceolatis (nec manifeste fusiformibus), levibus vel raro inferne papillatis; ovario viridi vel luteo-aurantiaco, haud albido; seminibus plerumque trigonis, subpyramidalibus plicatis et in angulis anguste alatis (nec sublenticulari-ellipticis, complanatis et in agulis late alatis).

Type:-Austronea marginata (Thunb.) Mart.-Azorín, M.B.Crespo, M.Pinter \& Wetschnig 
Bulbous geophyte. Bulb hypogeal, usually with compact scales but rarely loose, outer scales brownish and membranous. Roots thickened and branched. Leaves 1 to several per bulb, usually dark green, commonly leathery, terete or flat, rarely plicate, linear to ovate or rounded, usually smooth, glabrous to hairy or hispid. Inflorescence a capitate or subcorymbose raceme with long flower pedicels born on an elongated peduncle, rarely short racemose with short pedicels and peduncle, commonly the apex of the peduncle and the inflorescence nodding at early stages of development, but soon erect at anthesis. Pedicels of buds very short forming a dense apical raceme, distinctly elongating at anthesis to form a capitate or subcorymbose inflorescence, rarely also very short in flower. Bracts lanceolate, acute, the lowermost with a spur from a slight curve outgrowth abaxially to a long, wide spur with obtuse and lobate apex; bracteoles absent. Flowers pentacyclic, trimerous, stellate, erect-patent, diurnal, usually opening in the afternoon and withering in the evening. Flower buds usually reddish or brownish-green. Tepals 6 , biseriate, usually connate at the base to form a cup and patent free portion of tepals, rarely almost free from the base and spreading; adaxial side of tepals reddish, brownish, greenish or yellowish, rarely almost white; abaxial side of tepals with a distinct reddish, brownish, or greenish darker central band. Stamens 6, erect or spreading, not connivent to the style; filaments filiform to flattened, usually connate to the perigone and arising at the end of the perigone tube, but sometimes almost free when tepals are not distinctly connate, straight or rarely sigmoid, smooth or rarely papillate below; anthers ovate to oblong, dehiscing by longitudinal slits along their whole length; pollen yellow. Ovary ovoid to oblong or subglobose, trigonous, brown, red or green, sometimes with white maculae, differentiated from the style. Style white, narrow, erect, exerted, straight or slightly curved. Stigma small, papillose and indistinctly trigonous. Capsule ovoid-globose, triloculate, loculicide, valves splitting to the base, with the withered perigone segments circumscissile below and forming an apical cap. Seeds up to 30 per capsule, black, shining, commonly trigonous in outline, tetrahedrally folded and narrowly winged along the angles, with subovoid embryo ending into a long filamentous hilum, testa loose and easily detachable from the endosperm, with colliculate testa cell walls.

Etymology:-Austronea (Austro-= south;-nea = referring to the genus Urginea). This name refers to part of the species traditionally named Urginea or more recently Drimia sensu lato in southern Africa, that represent a genus endemic to Southern Hemisphere. Urginea s.str., based on the first typification by Adamson (1942) (see Speta 1998b), is endemic to western Mediterranean Basin and includes only Urginea fugax Steinheil (1834: 328) and U. ollivieri Maire (1938: 453), as confirmed in our phylogenetic analyses.

Main diagnostic characters and taxonomic relationships:- Species of Austronea are easily distinguishable by a syndrome of morphological characters that allow clear recognition such as the usually leathery and thickened leaves; the subcorymbose or congested raceme commonly nodding at early developing stages, the reddish to greenyellowish tepals (see flower buds), which are usually connate at the base to form a distinct cup and patent free lobes, the filaments linear to lanceolate (not distinctly fusiform), smooth or rarely papillate below, the ovary green to yelloworange, and the seeds commonly trigonous in outline, tetrahedrally folded and narrowly winged along the angles. As commented above, flower and inflorescence general morphology approach Austronea to Fusifilum, a fact supported by our phylogenetic analyses in which both genera form strongly supported sister clades, but both differing in clear morphological characters. Apparently, flower morphology in Austronea is unspecialized, differing from that in Litanthus Harvey (1844: 314), Thuranthos Wright (1916: 233), Rhadamanthus Salisbury (1866: 37), and Rhodocodon Baker (1880: 280), supporting their generic identity within Urgineoideae in the last century. However, species of Austronea were already recognized as a distinct group within Drimia sensu lato by Manning \& Goldblatt $(2003,2007)$, to include the species related to Drimia marginata. The basic trimerous flower pattern in Hyacinthaceae is constant, as in most petaloid monocot families, and variation mainly regards degree of connation of tepals, adnation and/or connation of stamens and morphology of the gynoecium, which were the main basis for generic circumscriptions in the past. However, based on previous phylogenetic studies, it is evident that the latter flower characters, such as degree of connation of tepals and adnation of filaments, appeared several times in the evolution as convergent events related to independent and usually distant clades or genera (Martínez-Azorín et al. 2011). Furthermore, within clades or genera, these convergence events also occurred, rendering some of these single characters as not sufficient for generic circumscription. For instance, some genera in Ornithogaloideae, such as Nicipe Rafinesque (1837: 54), show flowers with free or rarely connate tepals (Martínez-Azorín et al. 2011). Degree of connation of tepals has also been used in the past to segregate genera in Urgineoideae. Among the genera with distinctly connate tepals, Drimia, Litanthus, Rhadamanthopsis (Obermeyer 1980: 137) Speta (1998b: 74), Rhadamanthus, Rhodocodon, or Urgineopsis Compton (1930: 107) are easily recognized. However, many other species described as Urginea or Drimia sensu lato from southern Africa show unspecialized flowers in which tepals vary from free to shortly connate (Adamson 1942, Baker 1897, Hilliard \& Burtt 1982, Huber 1969, Jessop 1977, Stedje 1987), and this was the basis for rejection of some genera in the subfamily, such as for instance Urgineopsis, which show shortly connate tepals (Manning et al. 
2004). This is also the case in Austronea, in which tepals are usually connate for ca. 1-1.5 mm to form a distinct cup but sometimes are almost free, and therefore, this character alone should not be used for generic circumscription. Both quantitative and qualitative characters of flower morphology must be combined with those of fruits and seeds and also vegetative, as it occurs in other plant families, and then solid groups of taxa can be accepted at genus rank, as shown by Martínez-Azorín et al. (2011). This syndrome of morphological characters allows confident identification of Austronea species and also a multigeneric treatment in Urgineoideae (M. Martínez-Azorín and collaborators, in preparation), being similar to that widely accepted in Hyacinthoideae, where Manning et al. (2004) accept 11 genera only for southern African taxa, plus several more in the Northern Hemisphere.

Ecology:- Species of Austronea are usually found on patches of open vegetation, in sandy or loamy soil, on flats or rocky ground on mountain slopes.

Distribution:-Western and southern regions of southern Africa, spanning southern Namibia and western and southern South Africa, reaching deeply inland of the southern African subcontinent.

Karyology:-Apparently not studied yet (cf. Goldblatt et al. 2012).

Number of species:- In the present revision, 18 species are accepted in Austronea. All are difficult to find in the field because of their cryptic appearance. Leaves are usually small and appressed to the ground and might also be wellcamouflaged. Moreover, they present delicate inflorescences with usually small flowers and their leaves are usually dry at flowering time. This fact, in combination with the poor conservation of flower structures in herbarium vouchers, confound the taxonomy of the group and explains why several species of this genus have remained unnoticed until now. Our field work in South Africa and Namibia, combined with the cultivation of numerous Austronea samples in the glasshouse in the last decade, also attest the existence of further undescribed species, still poorly known, that holds promise of further increase of the number of species in this genus.

Further observations:- Idothea Kunth (1843: 341) is the only described genus which includes a species of Austronea in its original concept. Ten species were included in the former fitting in general terms the characters of Drimia s.str., including Drimia media Jacquin (1795: 15), D. purpurascens Jacquin (1812: 48), D. ciliaris Jacquin (1795: 15), D. villosa Lindley (1830: pl.1346), D. elata Jacquin (1794: 15), D. pusilla Jacquin (1794: 15), and D. humilis Berg. ex Ecklon (1827: 2). In addition, Kunth (1843) included three more Idothea species, albeit in doubt as suggested by the question mark in their combinations; these include: Anthericum pusillum Jacquin (1795: 18), A. physodes Jacquin (1795: 18) (both currently placed in Fusifilum), and Anthericum marginatum Thunberg (1794: 63). The latter species is here included in Austronea. Idothea has been considered a synonym of Drimia by most recent authors. Stearn (1978) typified Idothea on Idothea elata (Jacquin 1794: 15) Kunth (1843: 343), and therefore fixed the use of that name, avoiding conflicts with Austronea.

\section{New combinations}

Austronea acarophylla (E.Brink \& A.P.Dold) Mart.-Azorín, M.B.Crespo \& A.P.Dold comb. nov. $\equiv$ Drimia acarophylla E.Brink \& A.P.Dold in S. African J. Bot. 69(3): 396 (2003), basionym. Type:-South Africa: Eastern Cape. Grahamstown (3326): Committees Drift, Tyefu Location (-BB), elevation 500 m, 22 August 1991, E. Brink 788 (holotype, GRA!; isotype, BOL!)

Austronea barkerae (Oberm. ex J.C.Manning \& Goldblatt) Mart.-Azorín, M.B.Crespo, M.Pinter \& Wetschnig comb. nov. $\equiv$ Drimia barkerae Oberm. ex J.C.Manning \& Goldblatt in Bothalia 33(1): 109 (2003), basionym. Type:-South Africa: Western Cape. Clanwilliam (3218): $5 \mathrm{~km}$ south west of Eedenkuil, Farm Draaihoek (-DD), open clay flats, 13 October 2001, J.C. Manning 2655A (holotype, NBG!; isotype, PRE!)

Austronea chalumnensis (E.Brink \& A.P.Dold) Mart.-Azorín, M.B.Crespo \& A.P.Dold comb. nov. $\equiv$ Drimia chalumnensis A.P.Dold \& E.Brink in S. African J. Bot. 70(4): 631 (2004), basionym. Type:-South Africa: Eastern Cape. Peddie (3327): Cornfields Farm, near Chalumna River, 5 km northwest of Kayser's Beach, $35 \mathrm{~km}$ southwest of East London (-BA), elevation 100 m, 25 October 2002, A.P. Dold 4619 (holotype, GRA!)

Austronea ecklonii (Baker) Mart.-Azorín, M.B.Crespo, M.Pinter \& Wetschnig comb. nov. $\equiv$ Urginea ecklonii Baker in Bot. Jahrb. Syst. 15(3, Beibl. 35): 6 (1892), basionym = Drimia ligulata J.C.Manning \& Goldblatt in Taxon 63(6): 1330 (2014). Type (lectotype, designated by Tang \& Weiglin 2001):-South Africa: Western Cape. Clanwilliam (3218): Olifantsrivier (-BD), September 1829 or 1830, Ecklon \& Zeyher Asphod. 128 (NBG-SAM!). Epitype (designated 
by Manning \& Goldblatt: in press.): South Africa: Wuppertal (3219): Cedarberg, Wolfberg (-AC), 3 October 1952 (fl. ex hort Dec 1952), E. Esterhuysen 20587 (BOL!). Note:-The lectotype of Urginea ecklonii consists of two inflorescences lacking leaves and bulbs. Accepting Tang \& Weiglin's (2001) current concept of this species, which is characterized by its lorate leaves, we accept the inclusion of $D$. ligulata as a synonym of $A$. ecklonii, according to Manning \& Goldblatt (in press).

Austronea fimbrimarginata (Snijman) Mart.-Azorín, M.B.Crespo, M.Pinter \& Wetschnig comb. nov. $\equiv$ Drimia fimbrimarginata Snijman in Bothalia 39(2): 234 (2009), basionym. Type:-South Africa: Western Cape. Vanrhynsdorp (3118): Knersvlakte, Farm Moedverloor, \pm 17 km NE of Koekenaap (-AD), on quartzite ridges, 22 July 2005, A.D. Harrower 2762 (holotype, NBG!; isotype, PRE!)

Austronea marginata (Thunb.) Mart.-Azorín, M.B.Crespo, M.Pinter \& Wetschnig comb. nov. $\equiv$ Anthericum marginatum Thunb., Prodr. Pl. Cap. 1: 63(1794), basionym $\equiv$ Idothea marginata (Thunb.) Kunth, Enum. Pl. [Kunth] 4: 346 (1843) $\equiv$ Drimia marginata (Thunb.) Jessop in J. S. African Bot. 43(4): 295 (1977). Type:-South Africa: Northern Cape. Calvinia (3119): Hantam, November 1774, A.D. Thunberg s.n. (holotype, UPS-8393 [digital image!])

Austronea pulchromarginata (J.C.Manning \& Goldblatt) Mart.-Azorín, M.B.Crespo, M.Pinter \& Wetschnig comb. nov. $\equiv$ Drimia pulchromarginata J.C.Manning \& Goldblatt in Bothalia 37(2): 185 (2007), basionym. Type:-South Africa: Northern Cape. Kamiesberg (3018): Farm Draaiklip (-AA), 31 October 1983, C.H. Stirton 9226 (holotype, NBG!)

Austronea pygmaea (A.V.Duthie) Mart.-Azorín, M.B.Crespo, M.Pinter \& Wetschnig comb. nov. $\equiv$ Urginea pygmaea A.V.Duthie in Ann. Univ. Stellenbosch 6: Sect. A, No. 2, 10 (1928), basionym $\equiv$ Fusifilum pygmaeum (A.V.Duthie) Speta in Phyton (Horn) 38(1): 69 (1998). Type (lectotype, designated by Martínez-Azorín et al. 2015: 169):-South Africa: Western Cape. Cape Town (3318): 'Stellenbosch Flats', (-DD), 3 June 1926, A. Duthie s.n. STE1603a (NBG bar code 0197707-0; the eleven bulbs with leaves on the left hand side of the label, under the collecting number 1603a).

Austronea trichophylla (Mart.-Azorín, A.P.Dold \& M.B.Crespo) Mart.-Azorín, M.B.Crespo \& A.P.Dold comb. nov. $\equiv$ Drimia trichophylla Mart.-Azorín, A.P.Dold \& M.B.Crespo in Syst. Bot. 41(4): 944 (2016), basionym. Type:-South Africa: Eastern Cape. Grahamstown (3326): Cradock Road, ca. 6 miles from BRU [Botanical Research Unit, currently Selmar Schonland Herbarium], Grahamstown (-AD), 13 November 1979, C. Vosa \& E. Brink s.n. (holotype, GRA!).

Austronea vermiformis (J.C.Manning \& Goldblatt) Mart.-Azorín, M.B.Crespo, M.Pinter \& Wetschnig comb. nov. $\equiv$ Drimia vermiformis J.C.Manning \& Goldblatt in Taxon 63(6): 1330 (2014), basionym $\equiv$ Drimia vermiformis J.C.Manning \& Goldblatt in Bothalia 37(2): 184 (2007), nom. inval. Type:-South Africa: Western Cape. Clanwilliam (3218): Clanwilliam Dam, picnic site along N7 near wall (-BB), 3 August 1987, P.L. Perry 3587 (holotype, NBG [leaf only]!)

Austronea virens (Schltr.) Mart.-Azorín, M.B.Crespo, M.Pinter \& Wetschnig comb. nov. $\equiv$ Urginea virens Schltr. in J. Bot. 35: 433 (1897), basionym $\equiv$ Drimia virens (Schltr.) J.C.Manning \& Goldblatt in Strelitzia 9: 712 (2000). Type (lectotype, designated by Manning \& Goldblatt 2007: 184):-South Africa: Western Cape. Wuppertal (3219): Cold Bokkeveld, Tweefontein (-CD), 24 January 1897, R. Schlechter 10127 (BOL!; isolectotypes: E!, GRA!, BM, K!, L, P, PRE!, S!, Z). Epitype (designated here): ibidem (E00193963!). Note:-The protologue of Urginea virens describes it as having "foliis [...] linearibus carnosulis, glabris, scapo brevioribus, ca. $2.5 \mathrm{~cm}$ [sphalm. 'mm'] longis [...]; scapo [...] glaberrimo nudo; staminibus suberectis, filamentis, anguste linearibus, apicem versus attenuatis, glabris, [...] ovario ovoideo-glabro; stylo subfiliformi apicem perigonii attingente". Two specimens are cited in the protologue: "In collibus carrooideis montis Packhuisberg, in ditione Clanwilliam, alt. c. 2000 ped., Jan. 1897, L.C. Leipoldt" and "In arenosis montium pone Tweefontein, in terra Konde Bokkeveld, alt. c. 5500 ped., 24 Jan. 1897; R. Schlechter, No. 10127" The study of the type material at BOL, and further isotypes at various herbaria, reveals that the two collections are heterogeneous, as Leipoldt's collection shows the lower third of the inflorescence peduncle covered by distinct longhispid papillae and whitish flowers and Schlechter's collection shows glabrous, smooth peduncle and brown-reddish flowers. Moreover, a further collection by H. Bolus 9103 mounted on the same BOL herbarium sheet shows hispid lower portion of the peduncle and whitish flowers. It is also clear that Leipoldt's material seen by Schlechter lacked leaves, as indicated by Leipoldt himself in the voucher in Berlin (B 10 0167492), and no traces of leaves were found 
in the isotypes. Therefore, it is evident that Schlechter described the vegetative characters and the smooth nature of the inflorescence peduncle of his $U$. virens based on his own material from Tweenfontein in the Cold Bokkeveld. The lectotype of $U$. virens was designated by Manning and Goldblatt (2007) on the specimen Schlechter 10127 deposited at BOL. This was a good solution fitting Schlechter' description and the current concept adopted of that species having linear, smooth, erect leaves; glabrous peduncle and brownish flowers. However, the material at BOL consists only of a single bulb with a peduncle lacking leaves and inflorescence and therefore the material is too poor for a confident indentification. Therefore, we here select an epitype deposited at Edinburgh (E00193963), which shows two complete plants in flower with some remnants of leaves and smooth peduncle (D. Harris pers. comm.). Furthermore, although no leaves are available for the collections from Clanwilliam (Leipoldt s.n. and Bolus 9103), we preliminarily include them in Austronea olifanta (described below), based on the white flowers, hispid base of peduncle and distribution. Regarding the circumscription of this species, Manning \& Goldblatt (2007) considered Drimia minor (Duthie 1928: 11) Jessop (1977: 306) as a synonym of Drimia virens (Schlechter 1897: 433) Manning \& Goldblatt (2000: 712). However, Urginea minor Duthie (1928: 11) is a distinct species of Fusifilum as shown by the original description "filamenta albida, compressa, $1.5 \mathrm{~mm}$ longa, in medio $0.33 \mathrm{~mm}$ lata [...] ovarium albidum" (Duthie 1928), a solution in agreement with the latest revision of Fusifilum (Müller-Doblies et al. 2001). Furthermore, Duthie (1928) illustrated in her plate number 2 both newly described Urginea pygmaea Duthie (1928: 10) (Plate 2: 1-12) and U. minor (Plate 2: 13-19). Both species show similar leaves, inflorescence, and capsules, due to the high degree of homoplasy in the subfamily. However, qualitative characters of flowers allow distinct recognition of these Urginea species as belonging to Austronea and Fusifilum respectively, as already commented upon above.

\section{Description of new species}

1. Austronea densiflora Mart.-Azorín, M.B.Crespo \& A.P.Dold sp. nov. (Fig. 5)

Ab Austronea ecklonii affinis folio ad marginem incrassato colliculato papillis minutissimis inconspicuis munito, sed hac bene diversa folio solitario (nec 2-4); inflorescentia et pedunculo multo brevioribus quam folio subaequantibus vel brevioribus (nec valde longioribus), et floribus breviter penduculatis (usque ad $3 \mathrm{~mm}$ per anthesin) in racemo densissimo dispositis (nec subcorymbosis et longipedunculatis).

Type:-SOUTH AFRICA. Western Cape. Oudtshoorn (3322): Oudtshoorn, Grootkop Nature Reserve, NE of Oudtshoorn (-CA), elev. 415 m, 28 September 2011 (in flower), M. Martínez-Azorin, J. Vlok, A.P.Dold \& A. Martínez-Soler MMA891 (holotype, GRA!; isotype, ABH59705!).

Herbaceous deciduous geophyte. Bulb hypogeal, ovoid, large and succulent, 30-50 $\times 22-35 \mathrm{~mm}$, usually forming clumps and some producing two inflorescences per bulb, not extended into a hypogeal neck, with pale brown membranous outer tunics and white fleshy tightly packed inner tunics. Roots fleshy, white, branched, 10-80 $\times 1 \mathrm{~mm}$. Leaf solitary, suberect, withered or almost withered at flowering time, aerial portion 20-80 $\times 10-16 \mathrm{~mm}$, lorate-oblong, rounded distally, flat, slightly curved, sometimes cucullate at the apex, dull dark green, leathery, smooth, margins slightly thickened and revolute, covered by minute papillae, with a short white hypogeal leaf portion conecting to the bulb. Inflorescence erect, as long as or usually shorter than leaves, raceme 10-12 mm long, dense, with 12-22 flowers; peduncle $1.8-2.5 \mathrm{~cm}$ long, erect, somewhat sinuous, purple, smooth, glabrous; pedicels up to $3 \mathrm{~mm}$ long at anthesis, patent to suberect; bracts ovate-lanceolate, ca. $2 \mathrm{~mm}$ long, clasping the pedicels, shortly spurred, the lowermost with a short curved outgrowth of $0.2 \mathrm{~mm}$ long, membranous, purplish. Flowers pentacyclic, trimerous, stellate, opening about noon and withering in the evening, 1-3 flowers open at a time, flower buds red; tepals 6 , entire, white with a reddish tinge on the adaxial side, reddish with a darker longitudinal central band on the abaxial side, slightly glandular at the apex, biseriate, inner and outers overlapping at the base, connate for ca. $1 \mathrm{~mm}$ to form a slight cup, free portions spreading; outer tepals narrowly lanceolate-oblong, 4.7-5.1 × 1.7-1.9 mm, flat; inner tepals narrowly ovate, 4.8-5.2 $\times 1.8-2 \mathrm{~mm}$, flat. Stamens 6 , erect, adnate to perigone for ca. $1 \mathrm{~mm}$; filaments white, fleshy, flat, narrowly triangular, 2.8-3.2 $\times 0.7-0.9 \mathrm{~mm}$, smooth; anthers yellow, oblong, ca. $1 \mathrm{~mm}$ long before dehiscence, dehiscing by longitudinal slits, with yellow pollen. Ovary pale green, ovoid to subglobose, somewhat truncate to the style, $2.6-2.8 \times 2 \mathrm{~mm}$; style white, columnar, 1.9-2.1 mm long, slightly deflexed and sinuous, trigonous in transversal section; stigma small and slightly papillate. Capsule and seeds unknown. 


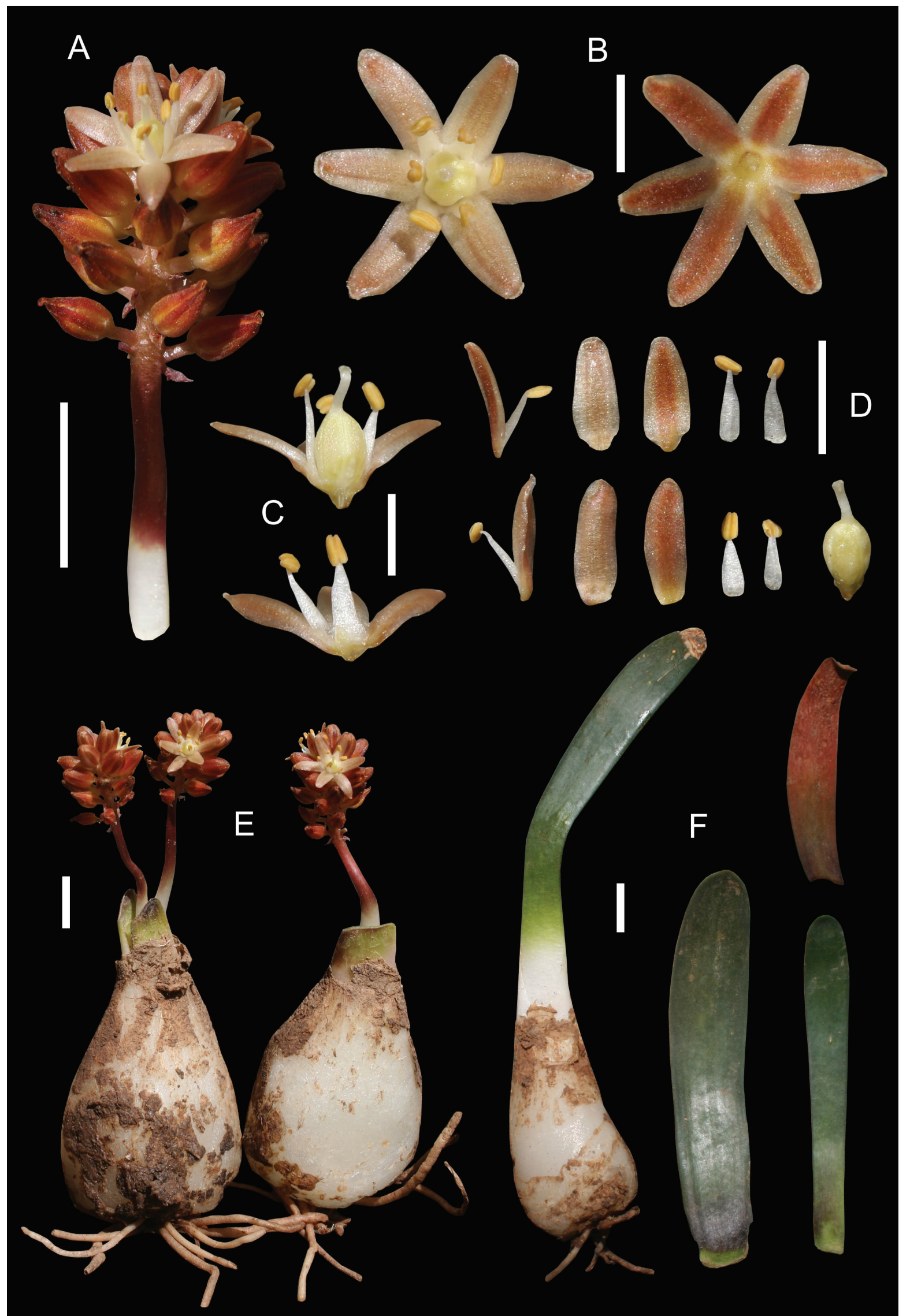

FIGURE 5. Austronea densiflora Mart.-Azorín et al. from the type locality, Grootkop Nature Reserve, NE of Oudtshoorn, Western Cape Province, South Africa, on 28 September 2011 corresponding to MMA891. A. Inflorescence; B. Flowers, frontal and dorsal views; C. Dissected flower in lateral view; D. Dissected flower showing tepals, stamens and gynoecium; E. Plants in flower; F. Bulb and leaves. Scale bars: A, E-F: $1 \mathrm{~cm}$; B-D: $5 \mathrm{~mm}$. 
Etymology:-Named after the dense inflorescence with very short flower pedicels.

Phenology:-Austronea densiflora flowers in September-October in the wild.

Habitat:- This species occurs in patches of open succulent vegetation on stony ground where plants are sheltered by rocks. It is restricted to the Little Karoo region and occurs in SKv11 Eastern Little Karoo and AT2 Gamka thicket vegetation types, characterized by indistinct aseasonal rainfall (mean annual precipitation ranging from 100 to 500 $\mathrm{mm}$ ), with a slight optimum in March and pronounced drought period in summer (December-January), and with a mean annual temperature of $17^{\circ} \mathrm{C}$ and fairly frequent frost (Mucina \& Rutherford 2006).

Distribution:-Austronea densiflora appears to be mainly restricted to the Little Karoo in the Western Cape Province of South Africa, with a disjunct population near Kareedouw in the Eastern Cape Province (Fig. 6).

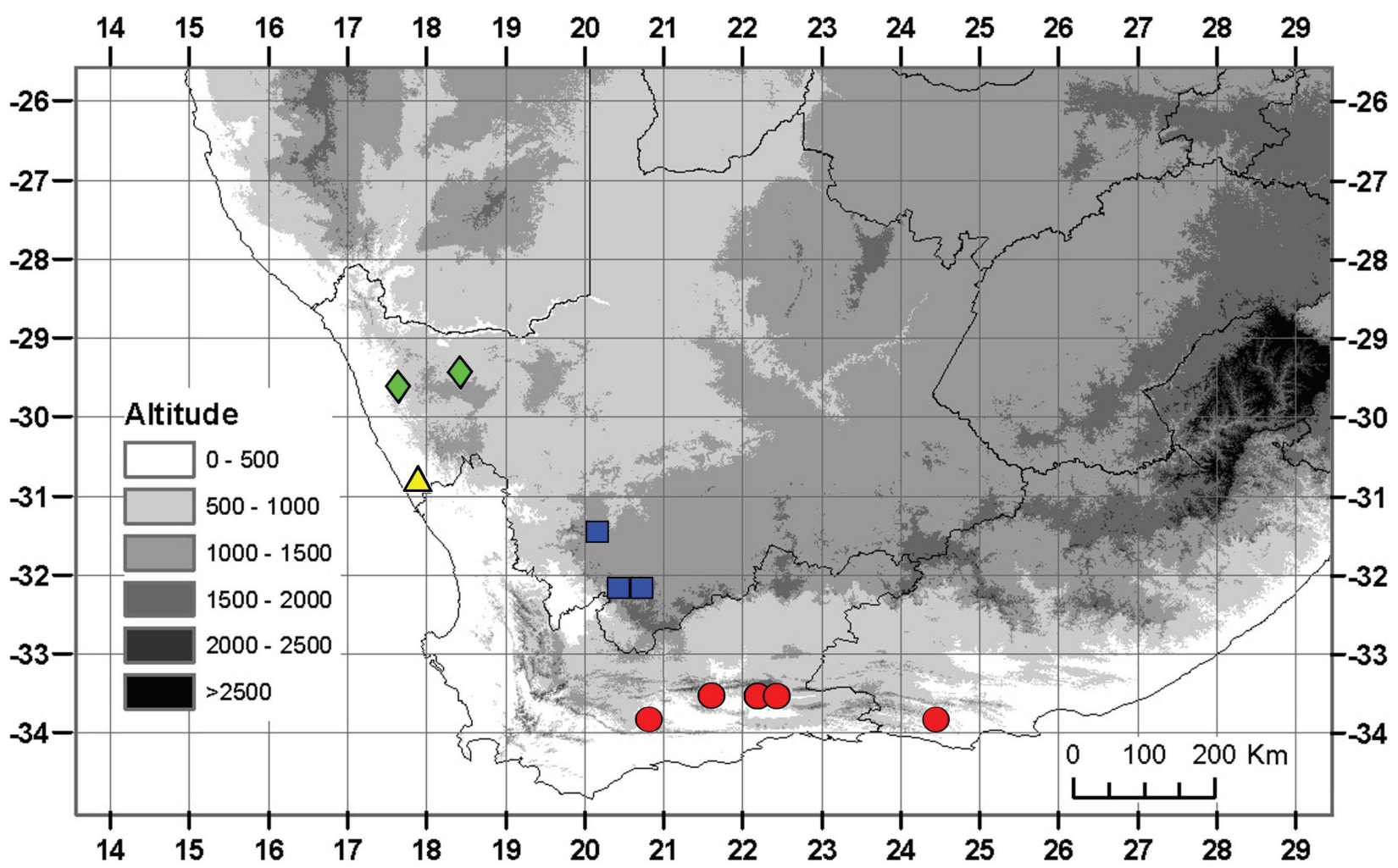

FIGURE 6. Distribution of Austronea species in southern Africa. A. densiflora Mart.-Azorín et al. (red circle), A. grandiflora Mart.Azorín et al. (blue square), A. hispidoplicata Mart.-Azorín et al. (yellow triangle) and A. papillosa Mart.-Azorín et al. (green diamond).

Diagnostic characters and taxonomic relationships:-Austronea densiflora was already recognised as an undescribed species, as "Drimia sp. nov.", on page 83 of "Plants of the Klein Karoo" by Vlok \& Schutte-Vlok (2010). Austronea densiflora is easily distinguishable by the combination of large, hypogeal bulbs, forming clumps; the solitary, lorate-oblong, rounded, leathery, smooth leaf with margins slightly thickened and revolute, covered by minute papillae; the very short inflorescence being as long as or usually shorter than leaves; peduncle $1.8-2.5 \mathrm{~cm}$ long, smooth and glabrous; raceme dense, $10-12 \mathrm{~mm}$ long; pedicels up to $3 \mathrm{~mm}$ long at anthesis; flowers stellate, white with a reddish tinge; and tepals $4.7-5.2 \mathrm{~mm}$ long, connate for ca. $1 \mathrm{~mm}$. Peduncle in $A$. densiflora is deviant in the genus in being very short, only shared by A. acarophylla and A. chalumnensis, but the 2 latter species differ in distinct leaf morphology (Brink \& Dold 2003, Dold \& Brink 2004). Regarding leaf morphology, the wide, flat leaf of $A$. densiflora resembles in general terms those of $A$. ecklonii $(=D$. ligulata), A. pulchromarginata and A. marginata. However, those three latter species clearly differ by distinct leaf shape and indumentum of leaf margin together with allopatric distribution (Manning \& Goldblatt 2007). Within those species, the closest to A. densiflora seems to be A. ecklonii, based on the thickened leaf margin colliculate or with minute, undifferentiated papillae. However, A. ecklonii clearly differs by the more numerous $2-3(-4)$ leaves, the much longer peduncle and the subcorymbose raceme with much longer pedicels. This species is restricted to the western mountains of the Cape Fold Belt.

Additional material studied (paratypes):-SOUTH AFRICA. Western Cape. Montagu (3320): Ladismith, 7 miles from Warmwaterberg along road to Barrydale (-DD), 1 August 1955 (in leaf), ex hort on 12 December 1955 (in flower), G. van Niekerk 567 (BOL!); Ladismith (3321): Calitzdorp District, Farm NE of Town (Besmkop) (-DA), elev. 
370 m, 29 September 2006 (in flower), P.M. Burgoyne \& M. Warrington 10673 (PRE843055!); Ladismith (3321): ca. $11 \mathrm{~km} \mathrm{SW}$ of Calitzdorp, Groenefontein Nature Reserve, near top of pass (-DA), elev. 408 m, 29 September 2011 (in leaf), M. Martinez-Azorín, A.P. Dold \& A. Martínez-Soler MMA945 (ABH59655!); ibidem, 18 September 2005, A.P. Dold s.n. (GRA); Ladismith (3321): Gamka N.R. Triangle (-DA), 9 September 2013 (in leaf), T. Rebelo s.n. (Photo on iSpot https://www.ispotnature.org/communities/southern-africa/view/observation/373024/mini-gifball); ibidem, 29 September 2006 (in flower), J. Kirkel s.n. (Photo on iSpot https://www.ispotnature.org/communities/southernafrica/view/observation/316707/hyacinthaceae); Oudtshoorn (3322): Oudtshoorn (-CA), October 1923 (in flower), Taylor 11778 (PRE!); Oudtshoorn (3322): 1/2 mile from Oudtshoorn (-CA), November 1932 (leaves), F.R. Long s.n. (BOL31787!); Oudtshoorn (3322): 6 km SW Dysseldorp (-CB), D.M. Cumming 11266 (Photo!). Eastern Cape. Steytlerville (3324): Joubertskraal River Pass, N of Kareedouw (-CD), D.M. Cumming 11204 (Photo at http://www. massonia.com/gallery?page $=12$ ).

\section{Austronea grandiflora Mart.-Azorín, M.B.Crespo, M.Pinter \& Wetschnig sp. nov. (Fig. 7)}

Ab Austronea vermiformi accedens folio unico angustoque, sed hac multo distincta folio parum carnosulo et magis complanato; floribus superne albicantibus vel laeviter roseocoloratis, majoribus, tepalis 7.6-8.6 mm long. (nec 4-5 mm long.) ad margines per anthesin longitudinaliter recurvatis, stylo longiore 3-4 mm long. (nec 1.5-2 mm long.).

Type:-SOUTH AFRICA. Northern Cape. Sutherland (3220): NW of Sutherland, $2 \mathrm{~km}$ from Sutherland-Calvinia R354 road, on turn off to Bo-Visrivier (-AB), elev. 1264 m, 15 April 2014 in flower ex hort at University of Alicante (Spain), M. Martínez-Azorín, A. Martínez-Soler \& R. McKenzie MMA828b (holotype, GRA!; isotype, ABH!).

Herbaceous deciduous geophyte. Bulb hypogeal, solitary, subglobose and usually depressed, 13-21 × 18-27 mm, extended into a hypogeal neck 2-3 cm long, with pale brown membranous outer tunics and white fleshy tightly packed inner tunics. Roots fleshy, white, branched, 5-30 × 0.6-1 mm. Leaf solitary, withered or almost withered at flowering time, aerial portion 25-52 $\times$ 4-6 mm, lorate-lanceolate, flattened, slightly contracted at ground level, dull dark green, usually showing a dark purplish ring at base, leathery, smooth, margins smooth or with minute papillae, prostrate to suberect, slightly curved, with a white hypogeal leaf portion connecting to the bulb neck. Inflorescence nodding in bud, raceme 2-5 mm long, capitate or subglobose, with 4-11 flowers; peduncle (2-)6-8 cm long, erect or flexuose, glabrous, smooth; pedicels 10-15(-22) mm long at anthesis, suberect to spreading; bracts ovate-lanceolate, 1.5-2 mm long, clasping the pedicels, spurred, the lowermost with a spur of 1-2 mm long, membranous, white with a central darker band. Flowers pentacyclic, trimerous, stellate, opening in the afternoon and withering in the evening, up to 5 flowers open at a time, flower buds red. Tepals 6 , entire, pinkish white on the adaxial side with a reddish darker longitudinal central band on the abaxial side, glandulous at the apex, biseriate, outer overlapping inner at the base, connate for ca. $1.5 \mathrm{~mm}$ to form a cup, free portions spreading; outer tepals lanceolate-oblong, 7.8-8.5 × 1.8-2.1 $\mathrm{mm}$, with margins distinctly longitudinally revolute at anthesis which touch together to form a narrow atenuate distal half; inner tepals lanceolate, 7.6-8.4 × 1.9-2 mm, with margins somewhat revolute at anthesis although not touching together. Stamens 6, suberect, adnate to perigone for ca. $1.5 \mathrm{~mm}$; filaments white, fleshy, subterete and attenuate to the apex, 6-7 $\times 0.8 \mathrm{~mm}$, smooth; anthers yellow, oblong, ca. $1 \mathrm{~mm}$ long before dehiscence, dehiscing by longitudinal slits, with yellow pollen. Ovary reddish, obovoid, somewhat truncate to the style, $2-2.5 \times 2 \mathrm{~mm}$; style white, columnar, 3-4 $\mathrm{mm}$ long, slightly contracted at the base, trigonous in transversal section; stigma small and slightly papillate. Capsule and seeds unknown.

Etymology:-Named after its large flowers when compared to most other species in Austronea, only approaching the size of A. fimbrimarginata.

Phenology:-Austronea grandiflora flowers in November-December in the wild. In cultivation at the University of Alicante (Spain) it flowered from March to May.

Habitat:- Grows on stony ground on inland plateaus between 1000 and $1500 \mathrm{~m}$ elevation with scarce vegetation in the Nama Karoo or Succulent Karoo biomes (Mucina \& Rutherford 2006).

Distribution:-Austronea grandiflora is known from some inland localities in the surroundings of Calvinia and the Roggeveld escarpment in the south western parts of the Northern Cape Province of South Africa (Fig. 6).

Diagnostic characters and taxonomic relationships:-Austronea grandiflora is easily identified by the single, flat, lorate-lanceolate leaf, with smooth, not thickened, margin only minutely papillate when dry; the subcorymbose inflorescence with large flowers; tepals 7.6-8.5 mm long, pinkish white on the adaxial side with a reddish band on the abaxial side, with margins distinctly revolute longitudinally at anthesis and style 3-4 mm long. Most species of Austronea show smaller tepals, only 3-5 mm long, except in A. fimbrimarginata up to $7 \mathrm{~mm}$ long, but the latter species showing very different leaves and flowers (Snijman \& Harrower 2009). The single, elongated leaf of Austronea 


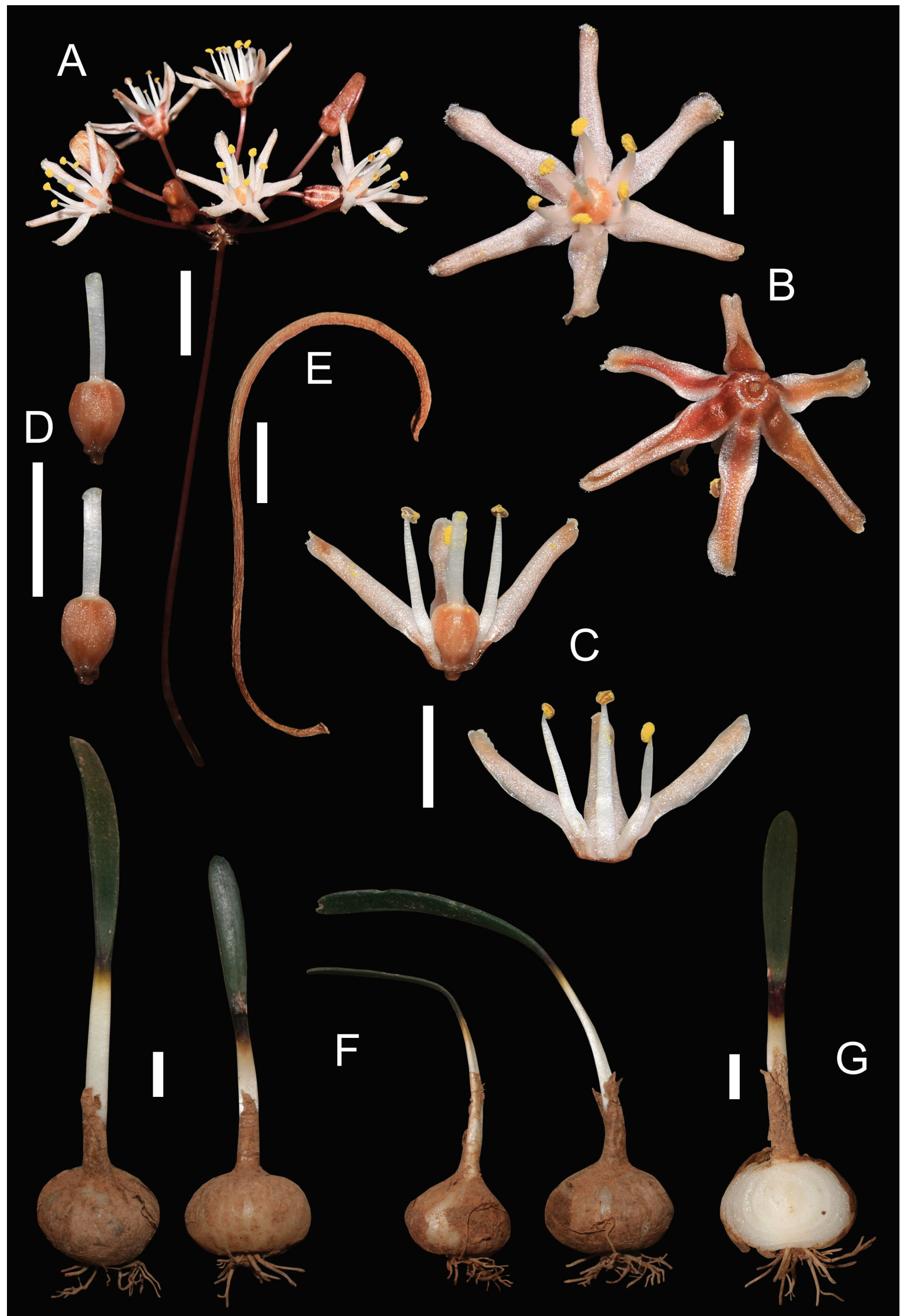

FIGURE 7. Austronea grandiflora Mart.-Azorín et al. from NW of Sutherland (type locality), Northern Cape Province, South Africa, in leaf in the wild on 4 September 2011 and in flower in cultivation in Alicante (Spain) on 15 March 2014 corresponding to MMA828. A. Inflorescence; B. Flowers, frontal and dorsal views; C. Dissected flower in lateral view; D. Gynoecia, lateral views; E. Withered leaf at flowering time; F. Bulb and leaves, lateral views; G. Dissected bulb with leaf. Scale bars: A, F-G: 1 cm; B-E: 5 mm. 
grandiflora is similar to that of $A$. vermiformis. However, the study of plants of the latter species from the type locality (Martínez-Azorín et al. MMA796, ABH59723!) show more succulent and less flattened leaves, and much smaller flowers, as said before. The original concept of A. vermiformis sensu Manning \& Goldblatt (2007) was very broad and included several populations with narrow elongated leaves and variable width, occurring from the Bushmanland in the Northern Cape to the Roggeveld and Nuweberg escarpments, extending to the Doring River and lower Olifants River valleys and as far east as the Little Karoo. Our study shows that this broad concept should be separated into two further species, one A. grandiflora occurring on the Roggeveld escarpment and the other A. linearis (see below) for populations from the Bushmanland to the Little Karoo, therefore restricting $A$. vermiformis to the lower Olifants River valley. Austronea marginata and $A$. ecklonii also share the flat, elongated leaf with A. grandiflora. However, $A$. marginata clearly differs by the shorter and wider leaf, with margins thickened and densely and minutely retrorsely scabridulous, and the pale brown small flowers with tepals only ca. $5 \mathrm{~mm}$ long (Manning \& Goldblatt 2007), among other characters. Austronea ecklonii (= Drimia ligulata) differs by the more numerous (up to 4), usually longer and wider leaves with thickened, papillate or colliculate margins and the small flowers as in A. marginata (Manning \& Goldblatt 2007).

Additional material studied (paratypes):-SOUTH AFRICA. Northern Cape. Calvinia (3120): 20 miles E of Calvinia on Brandvlei-Williston road (-AC), photos of flowers 8 December 1970, photo of leaf 22 July 1971, M. Thomas s.n. (NBG118025!, PRE!); Sutherland (3220): NW of Sutherland, 2 km from Sutherland-Calvinia R354 road, on turn off to Bo-Visrivier (-AB), elev. 1264 m, 4 September 2011 (in leaf), M. Martínez-Azorín, A. Martínez-Soler \& R. McKenzie MMA828a (ABH59543!); Sutherland (3220): ca. 24 km N Sutherland on R354, roadside (-BA), elev. 1486 m, 5 November 2015 in flower, M. Pinter s.n. WW05291 (ABH!).

\section{Austronea hispidoplicata Mart.-Azorín, M.B.Crespo, M.Pinter \& M.A.Alonso sp. nov. (Fig. 8)}

Ab Austronea barkerae affinis foliis lanceolatis vel ovato-lanceolatis conspicue pilosis, sed hac multo distincta folio solitario (nec 39), pilis unaequalibus longis albicantibusque sinuosis vel curvatis vel raro ramosis munito, longitudinaliter plicato, octocostato, quamquam in parte centrali subplano; tepalis albicantibus usque ad basin liberis (nec cupulato-connatis).

Type:-SOUTH AFRICA. Northern Cape. Hondeklipbaai (3017): ca. $10 \mathrm{~km} \mathrm{NE}$ of Kotzesrus on the way to Garies (-DB), elev. $160 \mathrm{~m}$, sandy soil on quartzitic ridge, 20 August 2017 (in leaf), M. Martínez-Azorín, M.B. Crespo, M.A. Alonso \& M. Pinter MMA1788 (holotype, GRA!; isotype, ABH76973!).

Herbaceous deciduous geophyte. Bulb hypogeal, solitary, ovoid to subglobose, 12-21 × 11-18 mm, extended into a hypogeal neck up to $1 \mathrm{~cm}$ long, with pale brown membranous outer tunics and white fleshy tightly packed inner tunics. Roots fleshy, white, branched, 15-25 $\times 1 \mathrm{~mm}$. Leaf solitary, withered or almost withered at flowering time, aerial portion 12-35 × 4-11 mm, ovate-lanceolate, flat, appressed to the ground, slightly leathery and succulent, green, adaxial side longitudinally plicate on the sides forming 4 longitudinal grooves on each side and flat along the central longitudinal band, covered by long hispid white trichomes (up to $2.5 \mathrm{~mm}$ long) of different lengths that are usually curved or sinuous and rarely branched, abaxial side smooth, flat and almost glabrous, except the adjacent areas to the leaf margins showing trichomes facing downwards. Inflorescence nodding in bud, raceme 2-6 $\mathrm{mm}$ long, capitate or subcorymbose, with 3-10 flowers; peduncle $8-12 \mathrm{~cm}$ long, erect, slightly flexuose, covered by minute papillae along the whole length; pedicels 5-9 mm long at anthesis, smooth, glabrous, spreading; bracts ovate-lanceolate, ca. $1 \mathrm{~mm}$ long, clasping the pedicels, spurred, the lowermost with a spur up to $1.5 \mathrm{~mm}$ long, membranous, white with a central darker band. Flowers pentacyclic, trimerous, stellate, opening in the afternoon and withered in the evening, only 1-2 flowers open at a time, flower buds reddish-brown; tepals 6 , entire, white on the adaxial side with a pale reddish-brown coloured longitudinal central band on the abaxial side, glandulous at the apex, biseriate, outer overlapping inners at the base, almost free from the base; outer tepals oblong, 4.3-4.5 × 1.6-1.7 mm; inner tepals oblong-lanceolate, 4.6-4.7 $\times$ 1.4-1.5 mm; both outer and inner with margins slightly revolute at anthesis. Stamens 6, spreading, shortly adnate to perigone for ca. $0.5 \mathrm{~mm}$; filaments white, terete, filiform, $2.9-3.1 \times 0.2 \mathrm{~mm}$, recurved and slightly sigmoid, smooth; anthers yellow, oblong, ca. $1 \mathrm{~mm}$ long before dehiscence, dehiscing by longitudinal slits, with yellow pollen. Ovary pale brown-reddish, ovoid, somewhat truncate to the style, 1.8-1.9 × 0.9-1 mm; style white, columnar, 2.6-2.8 mm long, erect, trigonous in transversal section; stigma small and slightly papillate. Capsule ovoid-globose, loculicide, valves splitting to the base, with the withered perigone segments circumscissile below and forming an apical cap. Seeds unknown.

Etymology:-Named after the unique leaf morphology of this species combining long hispid trichomes and longitudinally plicate leaf sides.

Phenology:-Austronea hispidoplicata flowers around September in the wild at the type locality. 


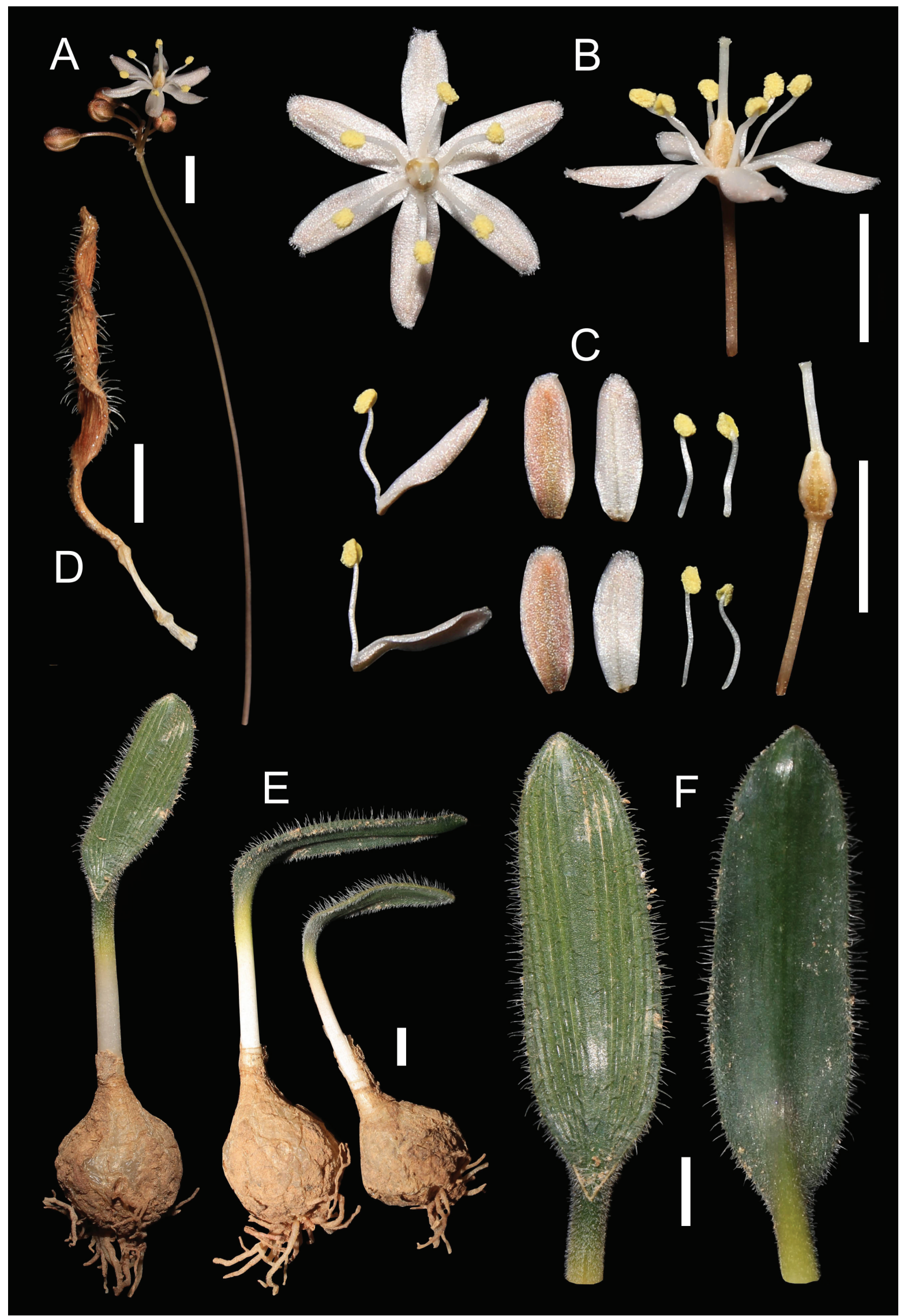

FIGURE 8. Austronea hispidoplicata Mart.-Azorín et al. from NE of Kotzesrus (type locality), Northern Cape, South Africa, in leaf in the wild on 20 August 2017 and in flower in cultivation in Alicante (Spain) on 13 October 2017 corresponding to MMA1788. A. Inflorescence; B. Flowers, frontal and lateral views; C. Dissected flower showing tepals, stamens and gynoecium; D. Withered leaf at flowering time; E. Bulbs with leaves, lateral views; F. Leaf, frontal and dorsal view. Scale bars: $5 \mathrm{~mm}$. 
Habitat:- This species occurs on gentle slopes and small koppies with gravelly or stony ground with quartz in the Succulent Karoo biome. Vegetation is classified as SKn4 Namaqualand Heuweltjieveld, characterised by winterrainfall climate with irregular rain events occurring mostly from May to August with almost no rain between November and February (MAP: $115 \mathrm{~mm}$ ) and frequent dew in winter. Mean annual temperature is ca. $17^{\circ} \mathrm{C}$ and frost hardly occurs (Mucina \& Rutherford 2006).

Distribution:-Austronea hispidoplicata is only known from the type locality in the surroundings of Kotzesrus in the Northern Cape Province of South Africa (Fig. 6).

Diagnostic characters and taxonomic relationships:-Austronea hispidoplicata is unique in having a solitary, ovate-lanceolate, flat leaf which is appressed to the ground, longitudinally plicate on the sides forming 4 longitudinal grooves on each side and a flat central longitudinal band adaxially, covered by long, hispid, white trichomes of different lengths that are usually curved or sinuous and rarely branched; and flat and almost glabrous abaxially with scarce trichomes near leaf margins. Other related species with hairy leaves, such as A. barkerae, A. olifanta or A. trichophylla, are never plicate nor striate and show different leaf morphology (Manning \& Goldblatt 2003, Martínez-Azorín et al. 2016). Flowers of $A$. hispidoplicata are peculiar in the genus as tepals are almost free and stamens are spreading and somewhat sinuous, although our genetic studies confirm its inclusion in Austronea.

\section{Austronea linearis Mart.-Azorín, M.B.Crespo \& A.P.Dold, sp. nov. (Fig. 9)}

Ab Austronea vermiformi affinis foliis coriaceis linearis atroviridisque, sed hac multo diversa nempe foliis usque ad 3 (nec semper solitariis), minute papillosis (nec laevibus), 2-3 mm lat. (nec 3-6 mm lat. et magis carnosis), synanthis vel proteranthis (nec semper proteranthis).

Type:-SOUTH AFRICA. Western Cape. Ladismith (3321): ca. 3 km E of Calitzdorp, on main road to Oudtshoorn (-DA), elev. 350 m, 28 September 2011 in flower and fruit, M. Martínez-Azorín, J. Vlok, A.P.Dold \& A. Martínez-Soler MMA928 (holotype, GRA!; isotype, ABH59622!)

Herbaceous deciduous geophyte. Bulb hypogeal, solitary, ovoid to subglobose, 14-28 × 13-27 mm, extended into a very short hypogeal neck, with white membranous outer tunics and white fleshy tightly packed inner tunics. Roots fleshy, white, branched, 8-50 $\times 0.6-1 \mathrm{~mm}$. Leaves 1-3, synanthous or withered at flowering time, aerial portion $38-90 \times 2-3 \mathrm{~mm}$, narrowly linear and elongated, flattened, sometimes slightly canaliculated at the base, leathery, dull dark green, apparently smooth but covered by minute papillae along the whole surface when dry (visible with magnifying glass), prostrate to suberect, straight or slightly curved, with a white hypogeal leaf portion of ca. $1 \mathrm{~cm}$ long conecting to the bulb neck. Inflorescence nodding in bud, raceme $2-5 \mathrm{~mm}$ long, capitate or subglobose, with 6-25 flowers; peduncle 8-16 cm long, purple, erect or flexuose, glabrous, smooth or rarely minutely papillose at the base; pedicels 10-15 $\mathrm{mm}$ long at anthesis, suberect to spreading, smooth; bracts ovate-lanceolate, $0.8-1 \mathrm{~mm}$ long, clasping the pedicels, spurred, the lowermost with a spur of 1.5-2 mm long, membranous, white with a central darker band. Flowers pentacyclic, trimerous, stellate, opening about noon and withering in the evening, 1-3 flowers open at a time, flower buds red; tepals 6 , entire, reddish, with a darker longitudinal central band on the abaxial side, slightly glandulous at the apex, biseriate, outer overlapping inner at the base, connate at the base for ca. $1.5 \mathrm{~mm}$ to form a distinct cup, free portions patent; outer tepals ovate, $4.8-5 \times 1.9-2 \mathrm{~mm}$; inner tepals ovate-lanceolate, $4.7-5 \times 1.8-2$ $\mathrm{mm}$, both inner and outer with margins somewhat revolute longitudinally at anthesis. Stamens 6 , suberect or slightly spreading, adnate to perigone for ca. $1.5 \mathrm{~mm}$; filaments white, fleshy, subterete and attenuate to the apex, $1.9-2.1 \times 0.3$ $\mathrm{mm}$, smooth; anthers yellow, oblong, ca. $0.8 \mathrm{~mm}$ long before dehiscence, dehiscing by longitudinal slits, with yellow pollen. Ovary green, ovoid, truncate to the style, 2.4-2.6 $\times 1.8 \mathrm{~mm}$; style white, columnar, $1.2 \mathrm{~mm}$ long, trigonous in transversal section; stigma small, glandulose and slightly papillate. Capsule ovoid-globose, loculicide, 6-9 × 5-6 $\mathrm{mm}$, valves splitting to the base, with the withered perigone segments circumscissile below and forming an apical cap. Seeds up to 30 per capsule, black, shining, ca. $3 \times 2 \mathrm{~mm}$, commonly trigonous in outline, tetrahedrally folded and narrowly winged along the angles, with subovoid embryo ending into a long filamentous hilum, testa loose and easily detachable from the endosperm, with colliculate testa cell walls.

Etymology:-Name alluding to the linear leaves characteristic of this species.

Phenology:-Austronea linearis flowers around September-October in the wild; fruits appear in NovemberDecember.

Habitat:- This species occurs on open patches of vegetation with stony ground in the Succulent Karoo and Nama Karoo biomes (Mucina \& Rutherford 2006).

Distribution:-Austronea linearis is known from southern Namibia and north western Northern Cape Province of South Africa as far south as the Little Karoo in Western Cape and the north-eastern regions of the Eastern Cape Province (Fig. 10). Large gaps among the cited populations exist and further studies are needed to evaluate the real extension of the distribution of this species. 


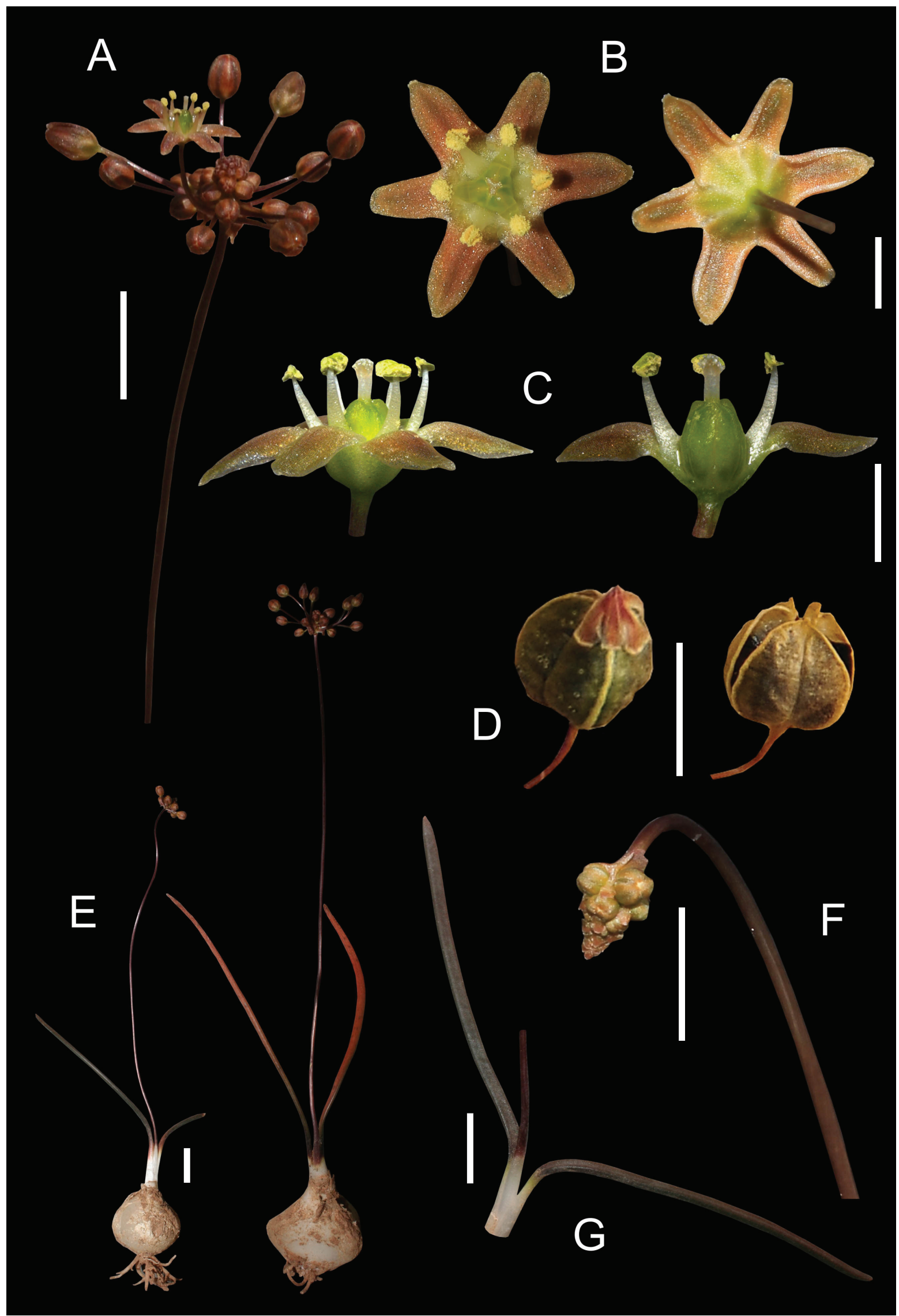

FIGURE 9. Austronea linearis Mart.-Azorín et al. from E of Calitzdorp (type locality), Western Cape, South Africa, in flower in the wild on 28 September 2011 corresponding to MMA928, fruits corresponding to MMA963. A. Inflorescence; B. Flowers, frontal and dorsal views; C. Flower and dissected flower in lateral view; D. Mature capsules, lateral views; E. Plants in flower; F. Young nodding inflorescence; G. Leaves. Scale bars: A, D-G: $1 \mathrm{~cm}$; B-C: $3 \mathrm{~mm}$. 


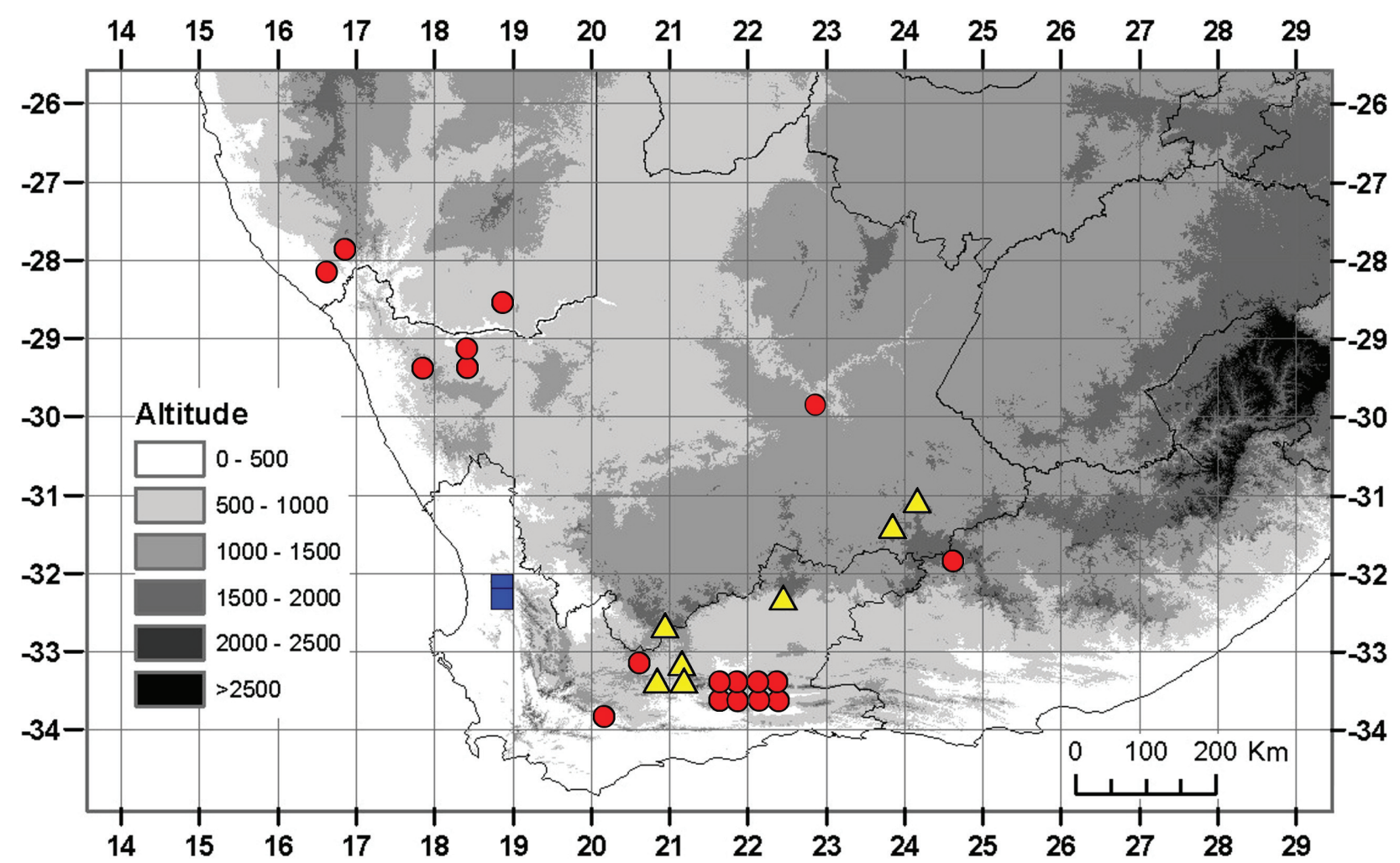

FIGURE 10. Distribution of Austronea species in southern Africa. A. linearis Mart.-Azorín et al. (red circle), A. olifanta Mart.-Azorín et al. (blue square) and A. pinguis Mart.-Azorín et al. (yellow triangle).

Diagnostic characters and taxonomic relationships:-Austronea linearis was already recognised as an undescribed species, as "Drimia sp. nov.", in a photograph included in the CD attached to the book "Plants of the Klein Karoo" by Vlok \& Schutte-Vlok (2010). Austronea linearis shows similar flowers to those of A. ecklonii, A. marginata, A. pulchromaginata and A. vermiformis but it differs in the 1-3, leathery, dull dark green, narrowly linear leaves, only $2-3 \mathrm{~mm}$ wide, which are synanthous or withered at flowering time, apparently smooth but covered by minute papillae along the whole surface under magnification when dry. The closest species, as far as the occurrence of the linear leaves is concerned, are A. vermiformis and A. trichophylla. However, these two species always show a solitary leaf, smooth and thicker in A. vermiformis, and lacking papillae and being distinctly hairy in A. trichophylla. Moreover, A. vermiformis is restricted to the western regions of the Western Cape Province and A. trichophylla is only known from the surroundings of Grahamstown, in the Eastern Cape Province, whilst $A$. linearis occurs from the inland western areas on the Eastern Cape Province and the Little Karoo to north-western Northern Cape Province and southern Namibia. As mentioned above, the concept of A. vermiformis by Manning \& Goldblatt (2007) is very wide and includes several populations that are here segregated as distinct species. Among them, the populations from the Little Karoo and Bushmanland are included in A. linearis. However, our field work revealed some variability in the studied populations. The populations from southern Namibia and Bushmanland (Northern Cape) constantly show a single leaf which is usually short and withered at flowering time whilst those from the Little Karoo and southern South Africa present 1-3 leaves, commonly 2, which are usually longer and mostly synanthous. However, inflorescence and flower sizes and morphology are almost identical among all those populations. That, together with the constant micropapillate leaves, support the acceptance of a single species. Further studies are required to evaluate the variability of these characters across its whole distribution.

Additional material studied (paratypes):-NAMIBIA. Warmbad (2818): Warmbad Dist., Witsand (-DB), elev. 950 m, 17 July 2005, P. Bruyns 10093 (NBG277883!); Witputz (2716): koppie east of mine at Rosh Pinah, on Namuskluft (-DD), elev. 454 m, 29 September 2004 (in flower), C.A. Mannheimer, Maggs-Kölling, G.L. et al. CM2661 (NBG!, PRE0865332!, WIND83726!); Oranjemund (2816): Distrikt Lüderitz-Süd, Obibberge (-BA), 20 September 1972 (in flower), H. Merxmüller \& W. Giess 28593 (PRE!). SOUTH AFRICA. Northern Cape: Springbok (2917): S of Steinkopf, ca. $2.5 \mathrm{~km} \mathrm{~S}$ of Spitzkop, ca. $500 \mathrm{~m} \mathrm{~W}$ of N7, quartzitic outcrop (-BD), elev. $842 \mathrm{~m}$, 29 July 2016 (in leaf), M. Martínez-Azorín, M.B. Crespo, M.A. Alonso, J.L. Villar, A. Vicente, J. Moreno \& A. Terrones MMA1544 
(ABH74326!); Gamoep (2918): Naib se Berg, eastern end, east of farm (-AD), elev. 827 m, 29 September 2015 (in flower), M. Martínez-Azorín, M. Pinter, M.B. Crespo \& M.A. Alonso MMA1250 (ABH74102!); Gamoep (2918): Naib se Berg, west of farm at eastern end, slopes going to south-facing entrance of main kloof (-AD), elev. $877 \mathrm{~m}, 29$ September 2015 (in flower), M. Martínez-Azorín, M. Pinter, M.B. Crespo \& M.A. Alonso MMA1253 (ABH74105!); Gamoep (2918): Naib se Berg, central section, on the way to south-facing entrance of main kloof (-AD), elev. $916 \mathrm{~m}$, 29 September 2015 (in flower), M. Martínez-Azorín, M. Pinter, M.B.Crespo \& M.A. Alonso MMA1262 (ABH74114!); Pofadder (2918): Pofadder, Bushmanland (-AB), 14 October 1954 (in leaf), ex hort on 13 May 1957 (in flower), E. Esterhuysen 23640a (BOL!); Prieska (2922): Griquastad District, Rudesheim (-DD), elev. 1400 m, 15 April 2003, P. Bruyns 9415 (NBG0212212-0!). Western Cape: Montagu (3320): Laingsburg C.P., Witteberg, Whitehill, northern slope (-BA), elev. 3500 feet, 24 October 1943 (in flower), R.H. Compton 15252 (NBG73279!); Montagu (3320): $13.5 \mathrm{~km}$ east of Bonnievale, near Drew (-CC), P.L. Perry s.n. (NBG123415!); Montagu (3320): near Montagu (-CC), M.R.L. 4600 (BOL!); Ladismith (3321): Matjiesvlei, at bottom of pass, near Elandspad at Gamkaspoort (-BC), elev. 1600 feet, 18 September 1985, J.H.J. Vlok 1148 (NBG140516!); Ladismith (3321): ca. $11 \mathrm{~km}$ SW of Calitzdorp, Groenefontein Nature Reserve, at eastern foot of mountain pass (-DA), elev. 326 m, 29 September 2011 in flower, $M$. Martinez-Azorín, A.P. Dold \& A. Martinez-Soler MMA963 (GRA!, ABH59651!); Ladismith (3321): Farm Droogkraal, $30 \mathrm{~km}$ NW of Oudtshoorn (-BD), 1 October 1980 (in flower), A. Bean s.n. (NBG123416!); Ladismith (3321): Road to Rooiberg pass, southwest of Radleight (-DA), elev. 1000 feet, 6 October 1971 (in flower), E.G.H. Oliver 3665 (NBG!); Ladismith (3321): Calitzdorp District, Farm NE of Town (Besemkop) (-DA), elev. 370 m, 29 September 2006, P.M. Burgoyne \& M. Warrington 10677 (PRE843054!); Ladismith (3321): Redstone Hills farm (-DB), 18 October 2017 (in flower), N. Crouch s.n. (Photo!); Oudtshoorn (3322): Oudtshoorn Div., $1 \mathrm{~m}$ NW of Cango Caves (-AC), 3 November 1928 (in flower and fruit), J.B. Gillett 1961 (BOL!, NBG288146!); Oudtshoorn (3322): Rust en Vrede, E of Cango (-AD), 15 October 2006 (in flower), A. Harrower 3158 (NBG206909!); Oudtshoorn (3322): south of turnoff to Kruisrivier on R62, ca. 20 km west of Oudtshoorn (-CA), elev. 248 m, 29 September 2011 in flower, $M$. Martínez-Azorín, A.P. Dold \& A. Martínez-Soler MMA961 (ABH!); Oudtshoorn (3322): $1.5 \mathrm{~km}$ east of Oudtshoorn, on road to De Rust (-CA), elev. 372 m, 30 September 2011 in flower, M. Martínez-Azorín, A.P. Dold \& A. Martínez-Soler MMA972 (GRA!, ABH59608!); Oudtshoorn (3322): $3 \mathrm{~km}$ east of Oudtshoorn, on road to De Rust (-CB), elev. 358 m, 30 September 2011 in flower, M. Martínez-Azorin, A.P. Dold \& A. Martínez-Soler MMA975 (GRA!, ABH59626!); Oudtshoorn (3322): Oudtshoorn, $3 \mathrm{~km}$ from Dysseldorp on road to Herold (-CB), elev. 400 m, 1 October 1989, N.P. Barker 683A (PRE743900!). Eastern Cape: Hanover (3124): 2.2 km NW of Nieu Bethesda (-DC), elev. 1435 m, 14 October 2011 in flower, M. Martínez-Azorín \& A. Martínez-Soler MMA1008 (GRA!, ABH59359!).

\section{Austronea olifanta Mart.-Azorín, M.B.Crespo, M.Pinter \& M.A.Alonso sp. nov. (Fig. 11)}

Ab Austronea barkerae affinis foliorum characteribus, sed hac diversa nempe foliis minus numerosis 1-4 (nec 3-9), a basi nec angustatis nec pseudopetiolatis, in maturitate glabrescentibus vel fere glabris (nec manifeste pilosis); floribus albidis (nec pallide brunneolis), ovario 2.8-3.1 mm long. (nec ca. $1.8 \mathrm{~mm}$ long.) et stylo longiore $1.8-2 \mathrm{~mm}$ long. (nec ca. $1 \mathrm{~mm}$ long.).

Type:-SOUTH AFRICA. Western Cape. Clanwilliam (3218): ca. 6 km south of Clanwilliam, near Clanwilliam-Citrusdal-Cederberg road crossing (-BB), elev. 124 m, 23 September 2015 (in flower), M. Martínez-Azorín, M.B. Crespo, M.A. Alonso \& M. Pinter MMA1170 (holotype, GRA!; isotype, ABH74854!).

Herbaceous deciduous geophyte. Bulb hypogeal, solitary, ovoid to subglobose, 11-25 × 10-26 mm, extended into a short hypogeal neck up to $1.5 \mathrm{~cm}$ long, with pale brown membranous outer tunics and white fleshy tightly packed inner tunics. Roots fleshy, white, branched, 5-40 $\times 0.7-1 \mathrm{~mm}$. Leaves 1-4, rosulate, sessile, withered or almost withered at flowering time, aerial portion 15-35 $\times 2-8 \mathrm{~mm}$, from narrowly lanceolate to ovate-lanceolate with acute apex in young leaves to obovate with obtuse apex in older leaves, flattened, slightly canaliculated, green, somewhat leathery, smooth, young leaves distinctly hairy and ciliate, with somewhat retrorse hairs $0.5-1 \mathrm{~mm}$ long, older leaves wider and nearly glabrous, although usually sparsely hairy along the lower portions, prostrate to suberect, with a white hypogeal leaf portion connecting to the bulb neck. Inflorescence nodding in bud, raceme 2-4 mm long, capitate or subcorymbose, with 4-21 flowers; peduncle 9-24 cm long, erect, flexuose, distinctly papillose on the lower half; pedicels 2-5 mm long at anthesis, spreading, smooth; bracts ovate-lanceolate, ca. $1 \mathrm{~mm}$ long, clasping the pedicels, spurred, the lowermost with a spur up to $2.5 \mathrm{~mm}$ long, membranous, white with a central darker band. Flowers pentacyclic, trimerous, stellate, opening about noon and withering in the evening, only 1-2 flowers open at a time, flower buds white-green; tepals 6 , entire, white on the adaxial side with a green longitudinal central band on the abaxial side, slightly glandulous at the apex, biseriate, outer overlapping inner at the base, connate for ca. $1.5 \mathrm{~mm}$ to form a cup, free portions patent; outer tepals ovate, $3.8-4.6 \times 1.8-2 \mathrm{~mm}$, with margins only slightly revolute at anthesis; inner tepals oblong, 


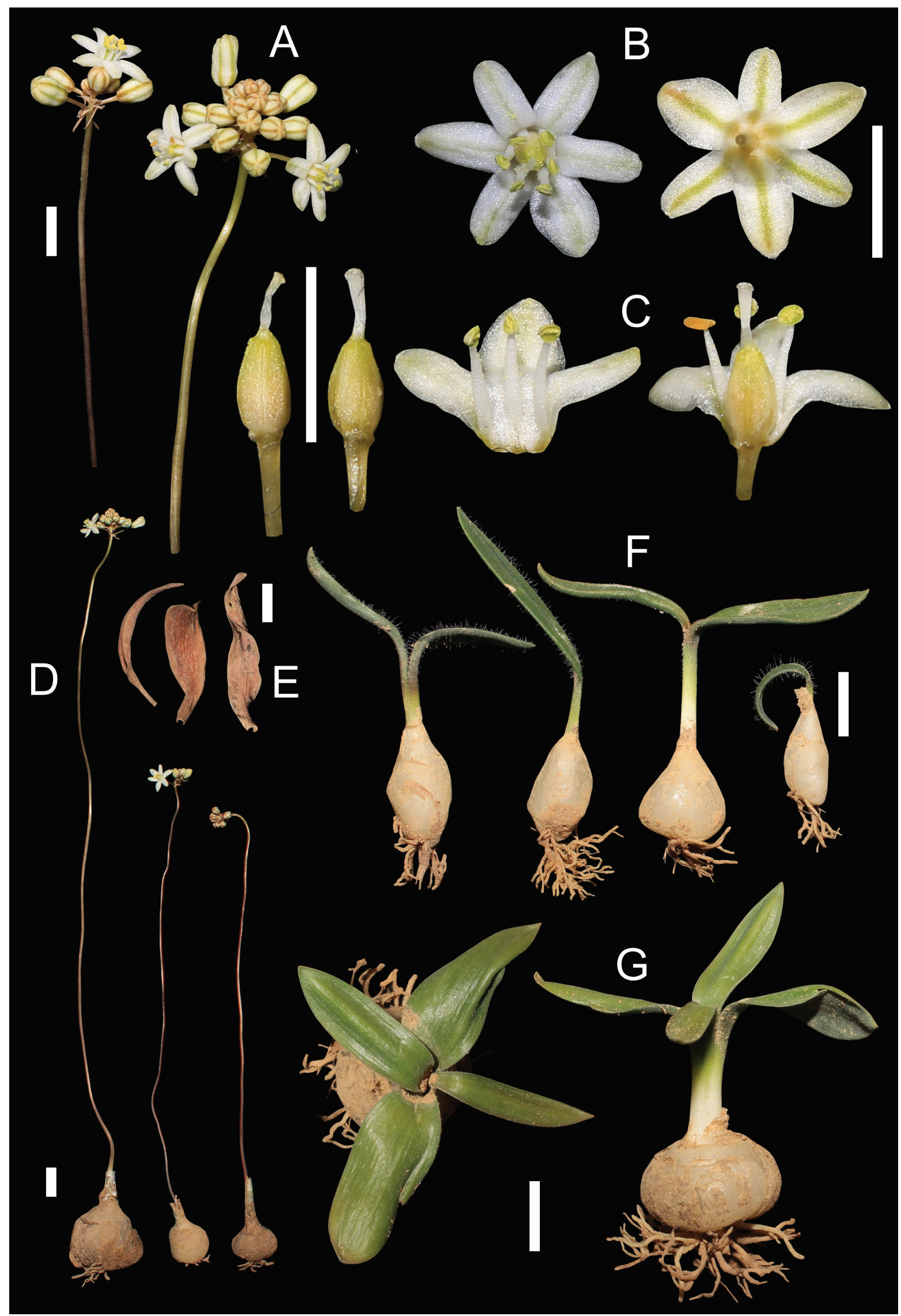

FIGURE 11. Austronea olifanta Mart.-Azorín et al. from S of Clanwilliam, (type locality), Western Cape, South Africa in flower on 23 September 2015 corresponding to MMA1170 and in leaves on 24 July 2016 corresponding to MMA1490-1491. A. Inflorescence; B. Flowers, frontal and dorsal views; C. Dissected flower in lateral view; D. Plants in flower; E. Withered leaves at flowering time; F. Young plants in leaf; G. Mature plants in leaf. Scale bars: A-C: $5 \mathrm{~mm}$; D-G: $1 \mathrm{~cm}$. 
3.7-4.4 × 1.7-1.9 mm, more or less flat. Stamens 6 , suberect or slightly spreading, adnate to perigone for ca. $1 \mathrm{~mm}$; filaments white, fleshy, subterete and attenuate to the apex, 2.6-2.8 $\times 0.4 \mathrm{~mm}$, smooth; anthers yellow, oblong, ca. 1 $\mathrm{mm}$ long before dehiscence, dehiscing by longitudinal slits, with yellow pollen. Ovary yellowish to pale green, ovoid, somewhat truncate to the style, $2.8-3.1 \times 1.5 \mathrm{~mm}$; style white, columnar, $1.8-2 \mathrm{~mm}$ long, slightly contrated at the middle, trigonous in transversal section; stigma small and slightly papillate. Capsule and seeds unknown.

Etymology:-Named after the Olifants River valley where the type locality of $A$. olifanta is located near Clanwilliam in the Western Cape Province of South Africa.

Phenology:-Austronea olifanta flowers around September in the wild at the type locality and leaves are present in July-August.

Habitat:-This species grows on sandy soil derived from Table Mountain sandstone on rocky ground with open vegetation classified as FFs3 Olifants Sandstone Fynbos, with mean annual precipitation ranging from 250-700 mm, peaking May to August, with 3-10 days of frost per year (Mucina \& Rutherford 2006).

Distribution:-Austronea olifanta is only known from the surroundings of Clanwilliam and Pakhuis Pass in the Western Cape Province (Fig. 10).

Diagnostic characters and taxonomic relationships:-Austronea olifanta is characterized by the $1-4$, sessile, lanceolate to obovate, flattened to slightly canaliculate leaves, distinctly hairy in young plants with cilia of $0.5-1 \mathrm{~mm}$ long, and almost glabrous in older mature plants but usually shortly hairy along the lower portions; inflorescence subcorymbose on an elongate peduncle; tepals white on the adaxial side with a green central band on the abaxial side, 3.7-4.6 mm long, connate for ca. $1.5 \mathrm{~mm}$ to form a cup, and patent free portions. Inflorescence, flower size and morphology of $A$. olifanta resemble those of several species in the genus, such as A. barkerae, A. ecklonii, A. marginata, A. pulchromarginata, A. trichophylla and A. vermiformis. However, leaf morphology of these species is clearly different (Manning \& Goldblatt 2003, 2007, Martínez-Azorín et al. 2016). Among them, A. trichophylla and $A$. barkerae show hairy leaves, however A. trichophylla differs from A. olifanta by the single, narrowly linear, thickened leaf and is restricted to the surroundings of Grahamstown in the Eastern Cape Province. The closest species to $A$. olifanta is $A$. barkerae with respect to the leaf and flower morphology, but the latter differs by the more numerous (3-)5-7(-9) leaves, which are narrowed into a pseudopetiole, always distinctly hairy at least on the abaxial surface in mature plants, the pale-brownish flowers, smaller ovary ca. $1.8 \mathrm{~mm}$ long and shorter style ca. $1 \mathrm{~mm}$ long (Manning \& Goldblatt 2003). Moreover, A. barkerae is endemic to the Piketberg Quartz Vygieveld (SKk8) — a very restricted vegetation unit characterised by quartz patches with slightly saline soils, as they are the quartz patches of Knersvlakte, within the succulent karoo unit, whilst $A$. olifanta is found in sandstone fynbos.

Additional material studied (paratypes):-SOUTH AFRICA. Western Cape. Clanwilliam (3218): Pakhuisberg, Clanwilliam, L.C. Leipoldt (BOL!); Clanwilliam (3218): Karroo hills Pakhuis, also Clanwilliam, common, L.C. Leipoldt (B100167492!); Clanwilliam (3218): In arenosis prope Clanwilliam, 300 feet, 2 October 1897, H. Bolus 9103 (BOL!); Clanwilliam (3218): Clanwilliam division, $\mathrm{N}$ of Citrusdal, 16 October 1935, L.E. Taylor 1225 (BOL!).

\section{Austronea papillosa Mart.-Azorín, M.B.Crespo, M.Pinter \& M.A.Alonso sp. nov. (Fig. 12)}

Ab Austronea virenti accedens foliis subteretis anguste linearibus suberectibusque, sed hac facile distinguenda foliis saepissime brevioribus 8-18 mm long. (nec multo longioribus), minute papillatis (nec laevibus glabrisque), pedunculo inflorescentiae et pedicellis floralibus tamen cum papillis patentibus ca. $0.1 \mathrm{~mm}$ long. dense obsitis (nec laevibus glabrisque); et ovario aurantiaco vel cinnamomeo, ellipsoideo, 3.5-4.2 mm long. (nec ovoideo et multo breviore).

Type:- SOUTH AFRICA. Northern Cape. Gamoep (2918): Naib se Berg, central section, on way to south facing entrance of main kloof (-AD), elev. 916 m, lower slopes covered with quartz, 28 September 2015 (in flower), M. Martinez-Azorín, M. Pinter, M.B. Crespo \& M.A. Alonso MMA1260 (holotype, GRA!; isotype, ABH74112!).

Herbaceous deciduous geophyte. Bulb hypogeal, solitary, ovoid to subglobose, 14-18 $\times 13-15 \mathrm{~mm}$, extended into a short hypogeal neck up to $0.5 \mathrm{~cm}$ long, with pale brown membranous outer tunics and white fleshy tightly packed inner tunics. Roots fleshy, white, branched, 5-15 $\times 0.4-0.7 \mathrm{~mm}$. Leaves 3-9, withered or almost withered at flowering time, aerial portion 8-18 $\times 1 \mathrm{~mm}$, linear, subterete, slightly flattened on the adaxial side, green, somewhat leathery, with scarce minute papillae, flattened and longitudinally striate when dry. Inflorescence nodding in bud, raceme 2-6 $\mathrm{mm}$ long, capitate or subcorymbose, with 3-10 flowers; peduncle 9-14 cm long, erect, flexuouse, covered by elongate, patent papillae ca. $0.1 \mathrm{~mm}$ long along the whole length; pedicels $2-5 \mathrm{~mm}$ long at anthesis, spreading, covered by the same papillae than the peduncle; bracts ovate-lanceolate, ca. $0.8 \mathrm{~mm}$ long, clasping the pedicels, spurred, the lowermost with a spur up to $1.5 \mathrm{~mm}$ long, membranous, white with a central darker band. Flowers pentacyclic, trimerous, stellate, opening in the afternoon and withered in the evening, only 1-2 flowers open at a time, flower buds pale orange; 


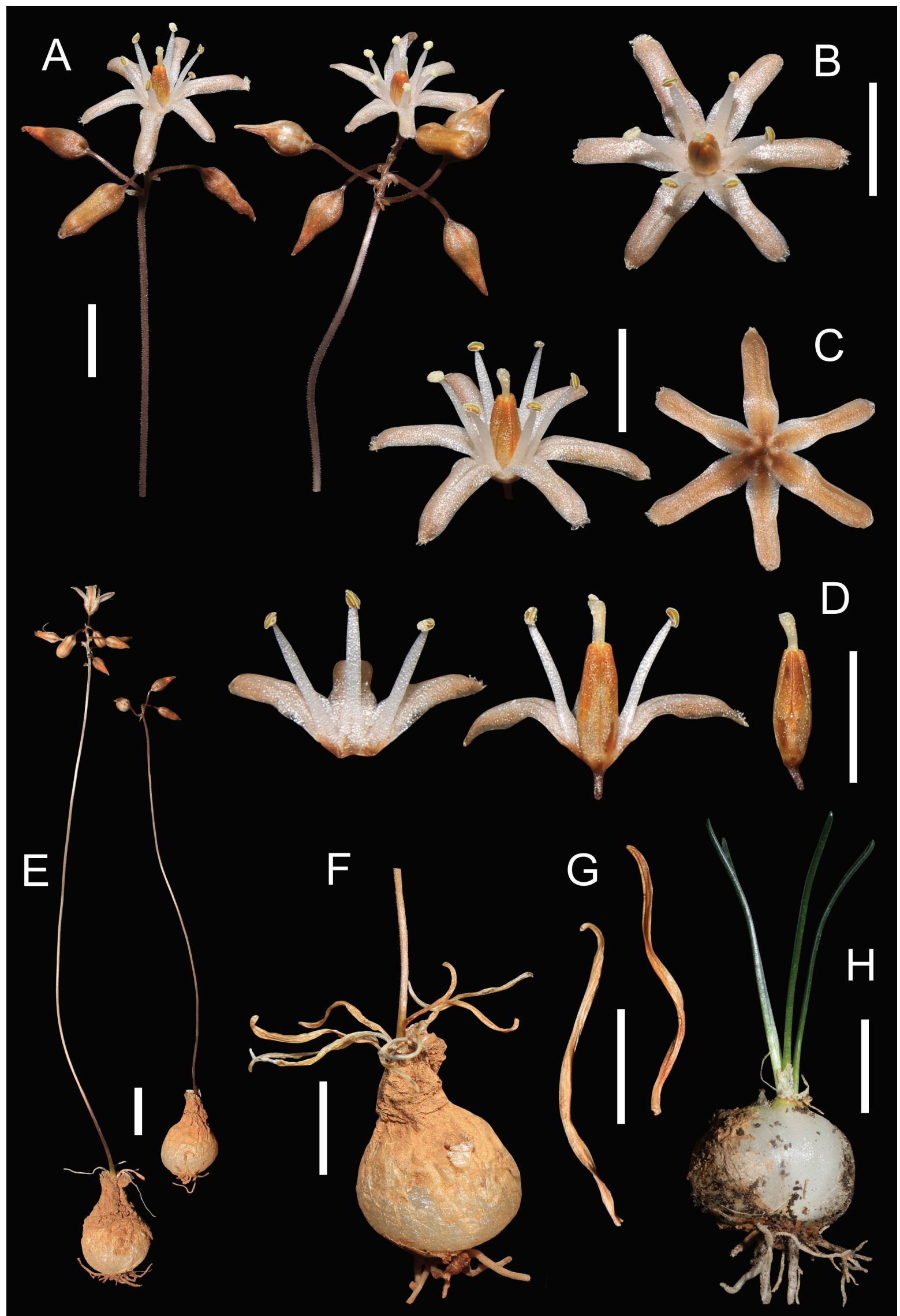

FIGURE 12. Austronea papillosa Mart.-Azorín et al. from Naib se Berg (type locality), Northern Cape, South Africa, in flower on 28 September 2015 corresponding to MMA1260 and with leaves in cultivation in Alicante (Spain) on 3 February 2018. A. Inflorescence; B. Flower, frontal view; C. Flowers, lateral and dorsal views; D. Dissected flower and gynoecium, lateral views; E. Plants in flower; F. Bulb with withered leaves; G. Detail of withered leaves; H. Bulb with fresh leaves. Scale bars: A-D, G: 5 mm; E-F, H: $1 \mathrm{~cm}$. 
tepals 6, entire, white with pinkish-orange tinge on the adaxial side with a pale orange to cinnamom coloured longitudinal central band on the abaxial side, glandulous at the apex, biseriate, outer overlapping inner at the base, connate for 1-1.5 $\mathrm{mm}$ to form a cup, free portions spreading; outer tepals oblong, 5-5.2 $\times 1.6-1.8 \mathrm{~mm}$; inner tepals oblong-lanceolate, $5-5.5 \times 1.5-1.6 \mathrm{~mm}$; both outer and inner with margins slightly revolute at anthesis. Stamens 6 , spreading, adnate to perigone for ca. $1 \mathrm{~mm}$; filaments white, fleshy, subterete or slightly flattened and attenuate to the apex, 3.1-3.3 $\times 0.4$ $\mathrm{mm}$, smooth; anthers yellow, oblong, ca. $1 \mathrm{~mm}$ long before dehiscence, dehiscing by longitudinal slits, with yellow pollen. Ovary orange to cinnamom colour, narrowly ovoid-lanceolate, distinctly elongated, somewhat truncate to the style, 3.5-4.2 × 1.4-1.5 mm; style white, columnar, 1.2-1.3 mm long, slightly curved or sinuous, slightly thickened at the apex, trigonous in transversal section; stigma small, capitate and slightly papillate. Capsule ovoid-globose, loculicide, valves splitting to the base, with the withered perigone segments circumscissile below and forming an apical cap. Seeds unknown.

Etymology:- Named after the distinctly papillose peduncle and pedicels together with the scarcely papillose leaves.

Phenology:-Austronea papillosa flowers around September in the wild at the type locality.

Habitat:-This species grows on gentle, quartz-covered slopes of the SKr18 Bushmanland Inselberg Shrubland and SKr19 Aggeneys Gravel Vygieveld the Bushmanland, and on surface shale rubble of the SKn2 Namaqualand Shale Shrubland in the the Skaap River region, west of Springbok. The area is characterised by winter-rainfall regime, with precipitation peaking between May and August precipitation and MAP (for various vegetation units) ranging from 120 to $200 \mathrm{~mm}$ and MAT of $16-17^{\circ} \mathrm{C}$, and with variable incidence of frost (Mucina \& Rutherford 2006).

Distribution:-Austronea papillosa is only known from the northwestern Northern Cape Province in South Africa, around the Naib se Berge and the Skaap River NW of Nababeep near Springbok (Fig. 6).

Diagnostic characters and taxonomic relationships:-Austronea papillosa shows a unique combination of morphological characters, such as the 3-9, narrowly linear, subterete leaves with scarce minute papillae; the elongated peduncle and pedicels covered by patent papillae ca. $0.1 \mathrm{~mm}$ long along the whole length; flowers white with a pinkish-orange tinge; tepals ca. $5 \mathrm{~mm}$ long, connate for $1-1.5 \mathrm{~mm}$ to form a cup, and spreading free portions; and ovary orange to cinnamon colour, narrowly ovoid-lanceolate, much longer than wide; and a white, short style. This species is unique in the genus in having distinctly papillate penducle and flower pedicels. Moreover, flower and gynoecium morphology is also unique. The narrowly linear, suberect, almost terete leaves approach A. pygmaea and A. virens, although both those species show smooth pedicels and upper portions of penduncle. Furthermore, the latter species usually shows much longer leaves. Austronea pygmaea and A. virens are restricted to the mountains in the western regions of the Western Cape Province and Cape Peninsula.

Additional material studied (paratypes):-SOUTH AFRICA. Northern Cape. Springbok (2917): Nababeep, Skaap River, NW of Nababeep (-DA), elev. 500 m, 16 November 2001 (in flower), P.V. Bruyns 8914A (NBG195966!).

\section{Austronea pinguis Mart.-Azorín, M.B.Crespo, M.Pinter \& M.A.Alonso, sp. nov. (Fig. 13)}

Ab Austronea acarophylla et A. vermiformi affinis folia solitaria, incrassata vel succulenta atque inflorescentia subcapitata, sed his bene diversa et facile distinguitur. A priore folia 15-25(40) $\times$ 5-9 mm, majora (in illa 6-14 $\times 1-4 \mathrm{~mm}$ ) et inflorescentiae pedunculo 7-14 cm, multo longiore differt. A posteriore precipue folia breviora et latiora (in illa 35-70 × 2-5 mm) inter alteros characteres discrepat.

Type:-SOUTH AFRICA. Western Cape. Montagu (3320): Rooinek Pass, ca. 18 km south of Laingsburg on R323 (-BD), elev. 759 m, ex hort at University of Alicante on 4 May 2018 in flower, M. Martinez-Azorín, M. Pinter, M.B. Crespo \& M.A. Alonso MMA1342b (holotype: GRA!; isotype: ABH!).

Herbaceous deciduous geophyte. Bulb hypogeal, solitary, ovoid to subglobose, 15-22 × 16-27 mm, slightly depressed in mature plants, extended into a hypogeal neck up to $20 \mathrm{~mm}$ long, with white membranous outer tunics and white fleshy tightly packed inner tunics. Roots fleshy, white, branched, 10-20 $\times 0.6-1 \mathrm{~mm}$. Leaf solitary, withered at flowering time, aerial portion 15-25(40) $\times 5-9 \mathrm{~mm}$, clavate, succulent, subterete to slightly flattened, leathery, dull dark green, smooth, suberect, with a white hypogeal leaf portion of 10-25 mm long conecting to the bulb neck. Inflorescence nodding in bud, raceme 3-6 mm long, capitate or subglobose, with 10-25 flowers; peduncle 7-14 cm long, reddishbrown, erect or flexuose, glabrous, smooth; pedicels 5-8 $\mathrm{mm}$ long at anthesis, suberect to spreading, smooth; bracts ovate-lanceolate, $0.7-0.9 \mathrm{~mm}$ long, clasping the pedicels, spurred, the lowermost with a spur of $0.6-0.8 \mathrm{~mm}$ long, membranous, purplish with a central darker band. Flowers pentacyclic, trimerous, stellate, opening about noon and withering in the evening, 1-3 flowers open at a time, flower buds red; tepals 6 , entire, reddish, with a darker longitudinal 


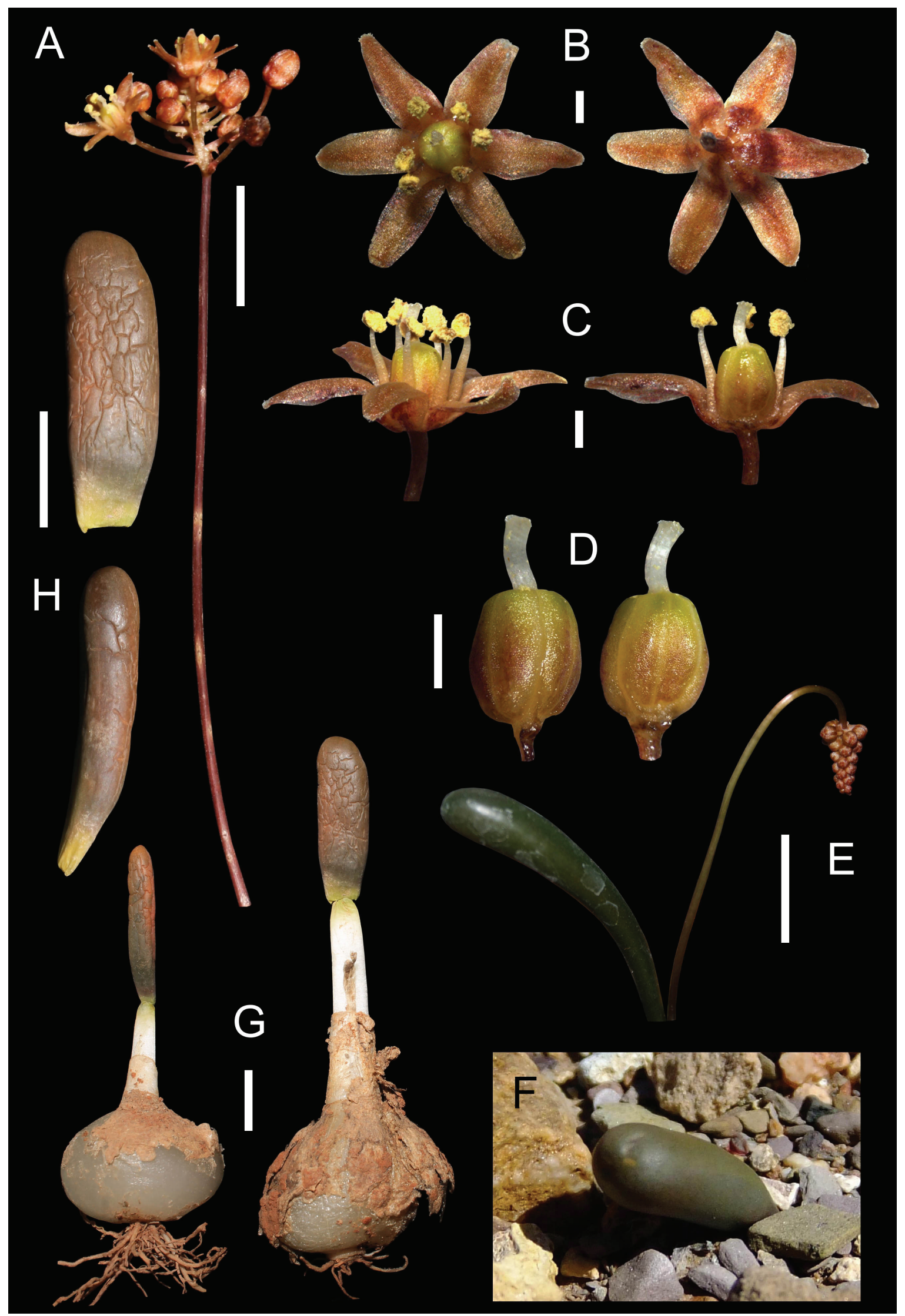

FIGURE 13. Austronea pinguis Mart.-Azorín et al. from S of Laingsburg, (type locality), Western Cape, South Africa; in cultivation on 4 May 2018 corresponding to MMA1342b (A-D); and on 17 April 2018 (E); from the type locality on 30 August 2012 (F); and on 3 October 2015 (G-H). A. Inflorescence; B. Flowers, frontal and dorsal views; C. Flower and dissected flower in lateral view; D. Gynoecia, lateral views; E. Plant in flower with nodding young inflorescence; F. Leaf in habitat (Photograph by J. Slade); G. Bulbs and withering leaves; H. Leaves starting to wither prior flowering. Scale bars: A, E, G-H: $1 \mathrm{~cm}$; B-D: $1 \mathrm{~mm}$. 
central band on the abaxial side, slightly glandulous at the apex, biseriate, outer overlapping inner at the base, connate at the base for 1-1.5 mm to form a distinct cup, free portions patent; outer tepals ovate, 3.5-4.5 $\times 1.3-1.5 \mathrm{~mm}$; inner tepals ovate-lanceolate, 3.4-4.3 $\times 1.2-1.4 \mathrm{~mm}$, both inner and outer with margins somewhat revolute longitudinally at anthesis. Stamens 6, suberect, adnate to perigone for ca. $1 \mathrm{~mm}$; filaments white, fleshy, subterete and attenuate to the apex, $1.8-2.3 \times 0.3 \mathrm{~mm}$, smooth; anthers yellow, oblong, ca. $0.8 \mathrm{~mm}$ long before dehiscence, dehiscing by longitudinal slits, with yellow pollen. Ovary green, ovoid, truncate to the style, $1.8-2 \times 1.6 \mathrm{~mm}$; style white, columnar, somewhat curved, $1.2 \mathrm{~mm}$ long, trigonous in transversal section; stigma small, glandulose and slightly papillate. Capsule and seeds unknown.

Etymology:-Name alluding to the short and succulent single leaf characteristic of this species.

Phenology:-Austronea pinguis flowers around December in the wild. In cultivation in the northern hemisphere (University of Alicante, Spain) it flowers around May.

Habitat:- This species is found on open patches of vegetation with stony ground mostly in the Succulent Karoo and Nama Karoo biomes (Mucina \& Rutherford 2006). The populations around Laingsburg are located in the SKv6 Koedoesberge-Moordenaars Karoo and the Nk11 Gamka Karoo vegetation types, characterized by indistinct aseasonal rainfall (mean annual precipitation ranging from 100 to $240 \mathrm{~mm}$ ), with a slight optimum in winter (March and MayAugust), with a mean annual temperature of $16^{\circ} \mathrm{C}$ and relatively high incidence of frost. The disjunct population around Richmond occurs in NKu4 Eastern Upper Karoo vegetation type and rainfall occurs mainly in autumn and summer, peaking in March (Mucina \& Rutherford 2006).

Distribution:- Most populations of Austronea pinguis are located around Laingsburg, north of the Swartberge mountain range, extending inland to the southern Roggeveld, Beaufort West and Richmond (Fig. 10).

Diagnostic characters and taxonomic relationships:- Austronea pinguis was first recognised as an undescribed species, as "Drimia sp nov Rouxpos", in a photograph included in the CD attached to the book "Plants of the Klein Karoo" by Vlok \& Schutte-Vlok (2010). Austronea pinguis is easily distinguished by the single, short and succulent leaf $(15-25(40) \times 5-9 \mathrm{~mm})$ and the subcapitate inflorescence borned on an elongated peduncle. This species seems to be related to $A$. acarophylla and $A$. vermiformis based on the single, thickened or succulent leaf. However, $A$. acarophylla differs by the smaller leaf $(6-14 \times 1-4 \mathrm{~mm})$ and much shorter peduncle of inflorescence (Brink \& Dold 2003 ) and $A$. vermiformis shows a much longer and thinner leaf $(35-70 \times 2-5 \mathrm{~mm}$ ), among other characters (Manning \& Goldblatt 2007).

Additional material studied (paratypes):-SOUTH AFRICA. Western Cape. Sutherland (3220): Laingsburg dist., Wilgerboom (-DB), elev. 1100 m, 30 May 2005 in leaf, flowers end of December, P.V. Bruyns 9998 (NBG02674580!); Beaufort West (3222): Stolshoek, Karoo National Park, W of Beaufort West (-AD), elev. 1250 m, 13 September 1989 (in flower), P.V. Bruyns 3977 (BOL2546!); Montagu (3320): Rooinek Pass, ca. $18 \mathrm{~km}$ south of Laingsburg on R323 (-BD), elev. 759 m, 3 October 2015 in leaf, M. Martínez-Azorín, M. Pinter, M.B.Crespo \& M.A. Alonso MMA1342 (ABH74912!); Montagu (3320): Rooinek Pass, south of Laingsburg (-BD), 30 August 2012 in leaf, J. Slade (Photo!); Ladismith (3321): Spitskopvlakte, $20 \mathrm{~km}$ E of Laingsburg (-AA), rocky shale flats, 12 May 2011 in leaf, $N$. Helme (Photo on iSpot at https://www.ispotnature.org/communities/southern-africa/view/observation/366351/drimiae-of-laingsburg); Ladismith (3321): near Rouxpos, on road from Laingsburg to Ladismith (-AC), 13 August 2007 in leaf, J. Vlok s.n. (Photo in Vlok \& Schutte-Vlok 2010). Northern Cape. Victoria West (3123): Richmond, slopes ca. 500 m north of town (-BD), D. Human s.n. (Photo!); Hanover (3124): Messfontein, Richmond (-AA), 13 April 2016 (in leaf), Dewidine (Photo on iSpot: https://www.ispotnature.org/communities/southern-africa/view/observation/614489/ drimia-single-leaf!).

\section{Identification key to Austronea species}

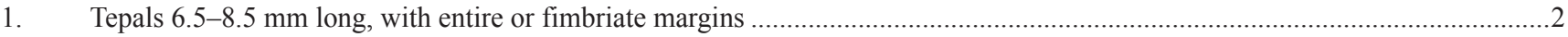

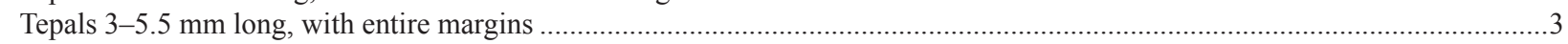
Leaf solitary, lorate-lanceolate, flattened, $4-6 \mathrm{~mm}$ wide, smooth; tepals entire ..................................................... grandiflora Leaves about 8, narrowly linear, ca. $1.5 \mathrm{~mm}$ wide, with minute, thickened, recurved trichomes; tepals distinctly fimbriate on mar-

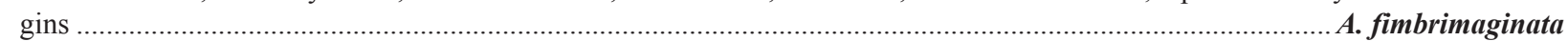

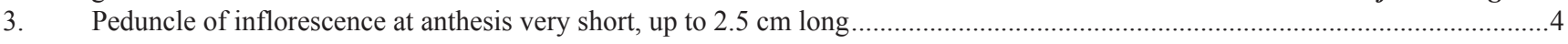

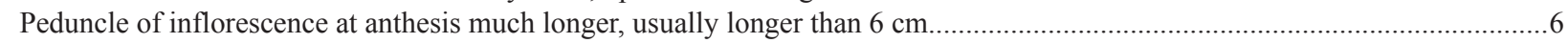

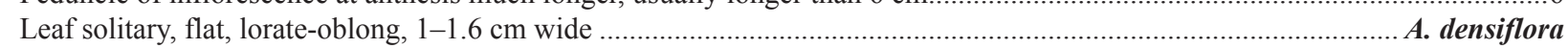

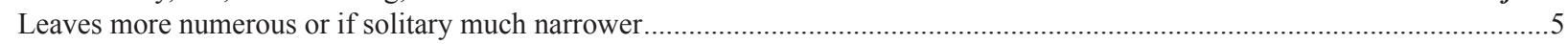

5. Leaves 2-6(-8), linear-lanceolate, rosulate, flattened, up to 10 times longer than wide; filaments minutely papillate on the lower portion; bulb scales loose A. chalumnensis Leaf solitary, or rarely 2, suberect, succulent, clavate and terete, up to 3 times longer than wide; filaments smooth; bulb scales 
Leaf solitary, with the adaxial side longitudinally plicate on the sides and flat along the central longitudinal band, covered by long hispid white trichomes; tepals free.

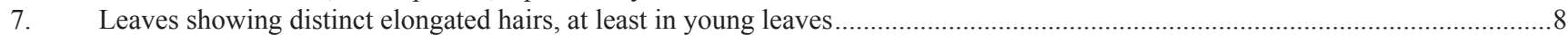

Leaves glabrous, but sometimes showing minute papillae especially on margins.....

8. Leaf solitary, narrowly linear, thickened, succulent, subterete or slightly flattened..........

A. trichophylla

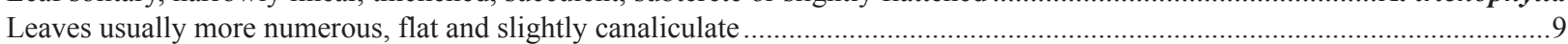

9. Leaves $1-4$, sessile, hairy in young plants and almost glabrous in mature plants; flowers white above; ovary $2.8-3.1 \mathrm{~mm}$ long .....

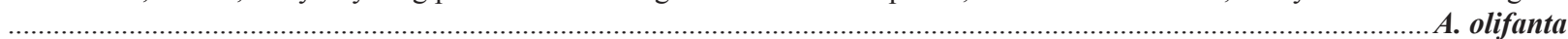
Leaves (3-)5-7(-9), narrowed in a pseudopetiole, distinctly hairy in mature plants; flowers pale-brownish above; ovary ca. $2 \mathrm{~mm}$

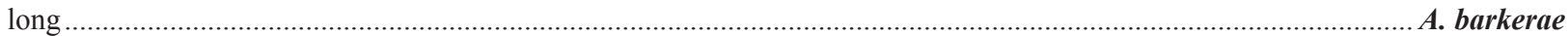

10. Leaves flat and wide with leaf margins thickened when dry and covered by minute papillae visible with magnifying glass ........ 11 Leaves subterete to ellipsoidal in section, from thickened and short to narrowly linear and elongated, lacking distinctly thickened margins with minute papillae

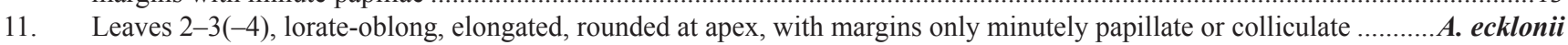
Leaves 1-2, ovate-oblong to suborbicular, apiculate at apex, with margins covered by distintly elongated papillae....................12

12. Leaves ovate-oblong, with homogeneous margins covered by retrorse, elongated papillae

A. marginata Leaves elliptical to suborbicular, with heterogeneous margins, only colliculate peripherally with a submarginal band of suberect or retrorse elongated papillae.....

13. Leaf solitary, thickened and succulent, $3-7 \mathrm{~mm}$ wide

A. pulchromarginata

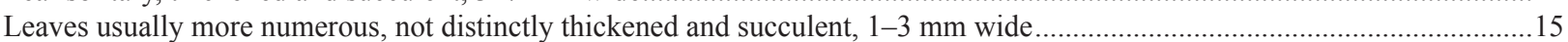

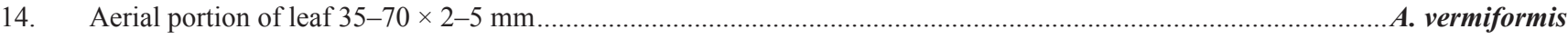

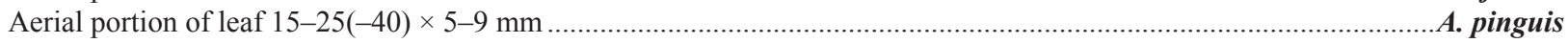

15. Peduncle of inflorescence and flower pedicels distinctly covered by elongate, patent papillae ca. $0.1 \mathrm{~mm}$ long along the whole

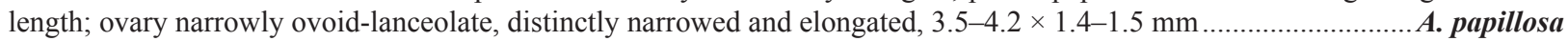
Peduncle of inflorescence glabrous, shortly scabridous or with patent papillae only on the lower half; flower pedicels smooth; ovary ovate to subglobose, not distinctly elongated with a different size......

16. Peduncle of inflorescence with hispid elongated papillae along the basal parts; leaves $1-2(-3) \mathrm{cm}$ long, spreading, with distinct

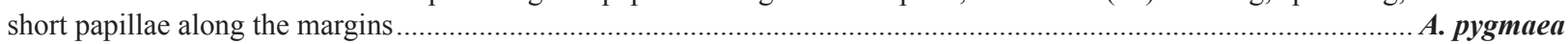
Peduncle of inflorescence smooth; leaves 3-9 cm long, suberect, smooth or minutely micropapillate along the whole surface ...17

17. Leaves $1-2(-3)$, slightly thickened and leathery, covered by minute micropapillae along the whole surface evident with magnifying glass when dry..... A. linearis Leaves $4-8$, thin, smooth.

A. virens

\section{Acknowledgements}

This work was partly supported by H2020 Research and Innovation Staff Exchange Programme of the European Commission, project 645636: 'Insect-plant relationships: insights into biodiversity and new applications' (FlyHigh) and the complementary supporting funds UAUSTI17-03 and ACIE17-01 (University of Alicante, Spain). We thank the curators of the herbaria who provided access to the specimens examined. D. Harris and L. Scott are thanked for checking morphological characters in the epitype of Urginea virens at E. Ute and D. Müller-Doblies are thanked for sharing vegetative material of Austronea samples included in the unpublished phylogenetic analyses. We thank J. Vlok for his help in the field in the Little Karoo and for showing us several populations of Austronea; L. Mucina kindly provided samples and ecological information of Austronea. D.M. Cumming and J. Slade kindly shared locality details of Austronea. Our thanks also go to all managers of the visited nature reserves for permission to work in areas under their care. The Department of Environment and Nature Conservation of Northern Cape Province (collecting and export permits numbers FLORA046/2010, FLORA047/2010, FLORA069/2011, FLORA070/2011, FLORA61/2/2015, FLORA61/2/2015, FLORA0057/2017, FLORA0058/2017) and CapeNature of Western Cape Province of South Africa (collecting and export permits numbers AAA008-00031-0028, 0027-AAA008-00699, 0028-AAA008-00203) provided permission to collect herbarium specimens to the first author and collaborators. The Ministry of Environment and Tourism of Namibia provided research/collecting permit (Permit number 2192/2016) and C. Mannheimer, S. Rugheimer and F. Chase kindly helped with field work in this country.

\section{References}

Adamson, R.S. (1942) Some peninsula species of Urginea. Journal of South African Botany 8: 237-242. 
Angiosperm Phylogeny Group (2003) An update of the Angiosperm Phylogeny Group classification for the orders and families of flowering plants: APG II. Botanical Journal of the Linnean Society 141: 399-436.

https://doi.org/10.1046/j.1095-8339.2003.t01-1-00158.x

Angiosperm Phylogeny Group (2009) An update of the Angiosperm Phylogeny Group Classification for the orders and families of flowering plants: APG III. Botanical Journal of the Linnean Society 161: 105-121.

https://doi.org/10.1111/j.1095-8339.2009.00996.x

Angiosperm Phylogeny Group (2016) An update of the Angiosperm Phylogeny Group Classification for the orders and families of flowering plants: APG IV. Botanical Journal of the Linnean Society 181: 1-20. https://doi.org/10.1111/boj.12385

Baker, J.G. (1880) Notes on a collection of flowering plants made by L. Kitching, Esq., in Madagascar in 1979. Journal of the Linnean Society, Botany 18: 264-281. https://doi.org/10.1111/j.1095-8339.1881.tb01257.x

Baker, J.G. (1892) Liliaceae novae Africae australis herbarii regii Berolinensis. Botanische Jahrbücher für Systematik 15: 4-8.

Baker, J.G. (1897) Liliaceae. In: Thiselton-Dyer, W.T. (Ed.) Flora Capensis 6. Reeve and Co., London, pp. 253-525.

Brink, E. \& Dold, A.P. (2003) Drimia acarophylla (Hyacinthaceae), a new species from Eastern Cape, South Africa. South African Journal of Botany 69: 396-400. https://doi.org/10.1016/S0254-6299(15)30322-7

Chase, M.W., Reveal, J.L. \& Fay, M.F. (2009) A subfamilial classification for the expanded asparagalean families, Amaryllidaceae, Asparagaceae and Xanthorrhoeaceae. Botanical Journal of the Linnean Society 161: 132-136. https://doi.org/10.1111/j.1095-8339.2009.00999.x

Compton, R.H. (1930) Novitates Africanae. Journal of Botany, British and Foreign, London 68: 102-107.

Crouch, N.R. \& Martínez-Azorín, M. (2015) Drimia edwardsii (Asparagaceae, Scilloideae), a new urgineoid species from the Mkhomazi River Valley of eastern South Africa. Phytotaxa 195 (2): 135-144. https://doi.org/10.11646/phytotaxa.195.2.2

Dold, A.P. \& Brink, E. (2004) Drimia chalumnensis (Hyacinthaceae-Urgineoideae), a new species from Eastern Cape, South Africa. South African Journal of Botany 70: 631-634. https://doi.org/10.1016/S0254-6299(15)30202-7

Duthie, A.V. (1928) Contribution to our knowledge of the Stellenbosch Flora. The species of Urginea of the Stellenbosch flats. Annale van die Universiteit van Stellenbosch 6, Sect. A, 2: 3-16.

Ecklon, C.F. (1827) Topographisches Verzeichniss der Pflanzensammlung von C. F. Ecklon. Steudel \& Hochstetter's Botanische ReiseVerein, Esslingen, 44 pp.

Goldblatt, P., Manning, J.C. \& Forest, F. (2012) A review of chromosome cytology in Hyacinthaceae subfamilies Urgineoideae and Hyacinthoideae (tribes Hyacintheae, Massonieae, Pseudoprospereae) in sub-Saharan Africa. South African Journal of Botany 83 : 134-144.

https://doi.org/10.1016/j.sajb.2012.07.023

Harvey, W.H. (1844) Litanthus, a new genus of Asphodeleae from South Africa. The London Journal of Botany 3: 314-315.

Hilliard, O.M. \& Burtt, B.L. (1982) Notes on some plants of Southern Africa chiefly from Natal: IX. Notes from the Royal Botanic Garden, Edinburgh 40: 247-298

Hooker, W.J. (1863) Ornithogalum capitatum. Curtis's Botanical Magazine 88: t. 5388.

Huber, H. (1969) Die Samenmerkmale und Verwandtschaftsverhaltnisse der Liliifloren. Mitteilungen der Botanischen Staatssammlung München 8: 219-538.

Jacquin, N.J. (1795) Icones plantarum rariorum 2 (16). C.F. Wappler, Vindobonae [Wien], 255 pp.

Jacquin, N.J. (1797) Observationes botanicae DXIX-DCLXXI. Collectaneorum Supplementum 5. Officina Wappleriana, Vindobonae [Wien], $220 \mathrm{pp}$

Jacquin, J.F. (1812) Eclogae plantarum rariorum aut minus cognitarum 1(3-4). Strauss, Wien, 20 pl.

Jessop, J.P. (1977) Studies in the bulbous Liliaceae in South Africa 7. The Taxonomy of Drimia and certain allied genera. Journal of South African Botany 43: 265-319.

Kunth, C.S. (1843) Enumeratio Plantarum omnium hucusque cognitarum secundum familias naturales disposita adjectis characteribus, differentiis et synonymis, vol 4. Sumtibus J.G. Cottae, Stutgardiae et Tubingae [Stuttgart et Tübingen], 752 pp.

Leistner, O.A. \& Morris, J.W. (1976) Southern African place names. Annals of the Cape Provincial Museum 12: 1-565.

Lindley, J. (1830) Drimia villosa. Edwards's botanical register 16: t. 1346.

Maire, R. (1938) Contributions à l'étude de la Flore de l'Afrique du Nord. Bulletin de la Société d'Histoire Naturelle de l'Afrique du Nord 29: 403-458.

Manning, J.C. \& Goldblatt, P. (2003) A new species and new combinations in Drimia (Urgineoideae) Bothalia 33: 109-111. 
https://doi.org/10.4102/abc.v33i1.2299

Manning, J.C. \& Goldblatt, P. (2007) New species of Drimia (Hyacinthaceae: Urgineoideae) allied to Drimia marginata from Western and Northern Cape, South Africa. Bothalia 37: 183-187.

https://doi.org/10.4102/abc.v37i1.313

Manning J.C., Goldblatt, P. \& Fay, M.F. (2004) A revised generic synopsis of Hyacinthaceae in Sub-Saharan Africa, based on molecular evidence, including new combinations and the new tribe Pseudoprospereae. Edinburgh Journal of Botany 60: 533-568.

Martínez-Azorín, M. \& Crespo, M.B. (2014) Validation of several species names in Hyacinthaceae. Taxon 63: $1327-1334$. https://doi.org/10.12705/636.21

Martínez-Azorín, M., Crespo, M.B. \& Juan, A. (2007) Taxonomic revision of Ornithogalum subg. Cathissa (Salisb.) Baker (Hyacinthaceae). Anales del Jardín Botánico de Madrid 64: 7-25.

https://doi.org/10.3989/ajbm.2007.v64.i1.47

Martínez-Azorín, M., Crespo, M.B. \& Juan, A. (2009) Taxonomic revision of Ornithogalum subg. Beryllis (Hyacinthaceae) in the Iberian Peninsula and the Balearic Islands. Belgian Journal of Botany 142: 140-162.

Martínez-Azorín, M., Crespo, M.B., Juan, A. \& Fay, M.F. (2011) Molecular phylogenetics of subfamily Ornithogaloideae (Hyacinthaceae) based on nuclear and plastid DNA regions, including a new taxonomic arrangement. Annals of Botany 107: 1-37.

https://doi.org/10.1093/aob/mcq207

Martínez-Azorín, M., Crespo, M.B. \& Dold, A.P. (2013a) Drimia cochlearis (Hyacinthaceae), a new species from South Africa. Systematic Botany 38: 332-338.

https://doi.org/10.1600/036364413X666831

Martínez-Azorín, M., Crespo, M.B., Dold, A.P., Wetschnig, W., Pinter, M., Pfosser, M., \& van Jaarsveld, E. (2013b) Sagittanthera (Hyacinthaceae, Urgineoideae), a new buzz pollinated genus from the Eastern Cape Province of South Africa. Phytotaxa 98 (2): 43-54. https://doi.org/10.11646/phytotaxa.98.2.2

Martínez-Azorín, M., Crespo, M.B., Dold, A.P., Pinter, M. \& Wetschnig, W. (2015) New combinations and lectotype designations in Asparagaceae subfam. Scilloideae. Phytotaxa 201 (2): 165-171.

https://doi.org/10.11646/phytotaxa.201.2.7

Martínez-Azorín, M., Dold, A.P. \& Crespo, M.B. (2016) Drimia trichophylla (Hyacinthaceae, Urgineoideae), a new species from the Eastern Cape Province, South Africa. Systematic Botany 41: 944-949.

https://doi.org/10.1600/036364416X694044

Martínez-Azorín, M. Crespo, M.B., Pinter, M. \& Wetschnig, W. (2017) Aulostemon (Asparagaceae, Scilloideae), a new genus from South Africa. Phytotaxa 321 (3): 287-293.

https://doi.org/10.11646/phytotaxa.321.3.6

Martínez-Azorín, M. Crespo, M.B., Pinter, M., Slade, J.M. \& Wetschnig, W. (2018) Iosanthus (Hyacinthaceae subfam. Urgineoideae), a new genus from southern Africa to include Ornithogalum toxicarium and its removal from Ornithogaloideae. Plant Biosystems. [in press]

Mucina, L. \& Rutherford M.C. (Eds.) (2006) The vegetation of South Africa, Lesotho and Swaziland. South African National Biodiversity Institute, Pretoria, 807 pp.

Müller-Doblies, U., Tang, J. \& Müller-Doblies, D. (2001) A revision of the genus Fusifilum Raf. 1837 (Hyacinthaceae of Southern Africa) 1. Ten new species in the genus Fusifilum vel prodromus Fusifili revisionis. Feddes Repertorium 112: 473-497. https://doi.org/10.1002/fedr.4921120708

Obermeyer, A.A. (1980) A new subgenus Rhadamanthopsis and two new species of Rhadamanthus. Bothalia 13: 137-139.

Pinter, M., Crespo, M.B., Ilg, I., Luidold, A.K., Martínez-Azorín, M., Müller-Doblies, U., Müller-Doblies, D., Pfosser, M. \& Wetschnig, W. (2013) Mucinaea (Hyacinthaceae-Urgineoideae), a remarkable new genus from Namaqualand (Northern Cape Province, South Africa). Phyton 53: 289-304.

Pfosser, M. \& Speta, F. (1999) Phylogenetics of Hyacinthaceae based on plastid DNA sequences. Annals of the Missouri Botanical Garden 86: $852-875$.

https://doi.org/10.2307/2666172

Pfosser, M. \& Speta, F. (2001) Bufadienolides and DNA sequences: on lumping and smashing of subfamily Urgineoideae (Hyacinthaceae). Stapfia $75: 177-250$

Pfosser, M. \& Speta, F. (2004) From Scilla to Charybdis-is our voyage safer now? Plant Systematics and Evolution 246: 245 -263.

Pfosser, M., Knirsch, W., Pinter, M., Ali, S., Dutta, S. \& Wetschnig, W. (2012) Phylogenetic relationships of Malagasy Hyacinthaceae. Plant Ecology and Evolution 145: 65-72.

https://doi.org/10.5091/plecevo.2012.590

Rafinesque, C.S. (1837) Flora Telluriana 3. H. Probasco, Philadelphia, PA, 100 pp. 
Salisbury, R.A. (1866) The genera of plants: a fragment containing part of Liriogamae. John van Voorst, London, 143 pp.

Schlechter, F.R.R. (1897) Decades plantarum novarum austro-africanarum. Journal of botany: British and Foreign 35: $428-433$.

Snijman, D.A. \& Harrower, A.D. (2009) A new species of Drimia (Urgineoideae) from the Knersvlakte, Western Cape, South Africa. Bothalia 39: 233-237.

Speta, F. (1998a) Hyacinthaceae. In: Kubitzki, K. (Ed.) The families and genera of vascular plants 3. Springer, Berlin, pp. $261-285$. https://doi.org/10.1007/978-3-662-03533-7_35

Speta, F. (1998b) Systematische Analyse der Gattung Scilla L. s.1. (Hyacinthaceae). Phyton (Horn) 38: 1-141.

Stearn, W.T. (1978) Mediterranean and Indian species of Drimia (Liliaceae) a nomenclatual survey with special reference to the medicinal squill, D. maritima (syn. Urginea maritima). Annales Musei Goulandris 4: 199-210.

Stedje, B. (1987) A revision of the genus Drimia (Hyacinthaceae) in East Africa. Nordic Journal of Botany 7: 655-666. https://doi.org/10.1111/j.1756-1051.1987.tb02034.x

Steinheil, A. (1834) Note sur le genre Urginea nouvellement formé dans la famille des Liliacées. Annales des Sciences Naturelles, Botanique, Sér. 2, 1: 321-332.

Tang, J. \& Weiglin, C. (2001) Urginea ecklonii Baker clarified and Fusifilum emdeorum sp. nova (Hyacinthaceae of South Africa). Feddes Repertorium 112: 499-508.

https://doi.org/10.1002/fedr.4921120709

Thiers, B. (2018) Index Herbariorum: A global directory of public herbaria and associated staff. New York Botanical Garden's Virtual Herbarium. Available from: http://sweetgum.nybg.org/ih/ (accessed 31 January 2018)

Thunberg, C.P. (1794) Prodromus plantarum Capensium: quas in promontorio Bonce Spei Africes vol. 1. J. Edman, Uppsala, 84 pp.

Turland, N.J., Wiersema, J.H., Barrie, F.R., Greuter, W., Hawksworth, D.L., Herendeen, P.S., Knapp, S., Kusber, W.-H., Li, D.-Z., Marhold, K., May, T.W., McNeill, J., Monro, A.M., Prado, J., Price, M.J. \& Smith, G.F. (Eds.) (2018) International Code of Nomenclature for algae, fungi, and plants (Shenzhen Code) adopted by the Nineteenth International Botanical Congress Shenzhen, China, July 2017. [Regnum Vegetabile 159]. Koeltz Scientific Books, Königstein, 254 pp.

Vlok, J. \& Schutte-Vlok, A.L. (2010) Plants of the Klein Karoo. Umdaus Press, Hatfield, 568 pp.

Wright, C.H. (1916) Diagnoses africanae: LXIX. Bulletin of Miscellaneous Information, Royal Gardens, Kew 1916: 229-235. https://doi.org/10.2307/4114331 